\title{
Exploring Rhodium(I) Complexes [RhCl(COD)(PR $)$ ] (COD = 1,5-Cyclooctadiene) as Catalysts for Nitrile Hydration Reactions in Water: The Aminophosphines Make the Difference
}

Eder Tomás-Mendivil, Rocío García-Álvarez, Cristian Vidal, Pascale Crochet, and Victorio Cadierno*

Laboratorio de Compuestos Organometálicos y Catálisis (Unidad Asociada al CSIC), Red ORFEO-CINQA - Centro de Innovación en Química Avanzada, Departamento de Química Orgánica e Inorgánica, Instituto Universitario de Química Organometálica “Enrique Moles”, Facultad de Química, Universidad de Oviedo, Julián Clavería 8, E33006 Oviedo, Spain

* To whom correspondence should be addressed. E-mail: vcm@uniovi.es 


\begin{abstract}
Several rhodium(I) complexes $\left[\mathrm{RhCl}(\mathrm{COD})\left(\mathrm{PR}_{3}\right)\right]$, containing potentially cooperative phosphine ligands, have been synthesized and evaluated as catalysts for the selective hydration of organonitriles into amides in water. Among the different phosphines screened, those of general composition $\mathrm{P}\left(\mathrm{NR}_{2}\right)_{3}$ led to the best results. In particular, complex $\left[\mathrm{RhCl}(\mathrm{COD})\left\{\mathrm{P}\left(\mathrm{NMe}_{2}\right)_{3}\right\}\right]$ was able to promote the selective hydration of a large range of nitriles in water without the assistance of any additive, showing a particularly high activity with heteroaromatic and heteroaliphatic substrates. Employing this catalyst, the antiepileptic drug rufinamide was synthesized in high yield by hydration of 4-cyano-1-(2,6-difluorobenzyl)-1H-1,2,3-triazole. For this particular transformation, complex $\left[\mathrm{RhCl}(\mathrm{COD})\left\{\mathrm{P}\left(\mathrm{NMe}_{2}\right)_{3}\right\}\right]$ resulted more effective than related ruthenium catalysts.
\end{abstract}

Keywords: Rhodium complexes, Aminophosphines, Hydration reactions, Nitriles, Amides, Rufinamide, Aqueous catalysis.

\title{
Introduction
}

The hydration of organonitriles is a relevant transformation in both academia and industry because the products of the reaction, i.e. primary amides, are versatile synthetic intermediates, as well as useful building blocks for the manufacture of pharmaceutical molecules and engineering polymers. ${ }^{1}$ Conventional protocols for hydrating nitriles involve the use of highly acidic/basic media under harsh reaction conditions, methods that usually cause partial over-hydrolysis of the amides into the corresponding carboxylic acids and do not tolerate many key functional groups. ${ }^{2}$ Nitrile hydratases (NHases), a family of biocatalysts comprising non-heme iron and non-corrinoid cobalt enzymes, have demonstrated great potential to promote the selective transformation of nitriles into amides under mild conditions. ${ }^{3}$ Indeed, NHases are now being used for the large scale production of acrylamide, nicotinamide, 5-cyanovaleramide and the antiepileptic amide drug levetiracetam (marketed under the trade name Keppra ${ }^{\circledR}$ ). 3,4 However, from a synthetic point of view, the high cost and substrate specificity of the currently available enzymes severely limit their use. Given their greater substrate scope and easier handling, methods based on homogeneous or heterogeneous metal-catalysts 
represent more attractive and powerful alternatives. ${ }^{5}$ In this context, remarkable results have been obtained in recent years using homogeneous ruthenium catalysts containing as auxiliary ligands pyridyl-phosphines, ${ }^{6}$ aminoaryl-phosphines, ${ }^{7}$ thiazolyl-phosphines, ${ }^{8}$ 1,3,5-triaza-7-phosphaadamantane (PTA) and related cage-like aminophosphines, ${ }^{9}$ tris(dimethylamino)phosphine ${ }^{10}$ or phosphinites $\left(\mathrm{R}_{2} \mathrm{POH}\right){ }^{11,12}$ The excellent activities were in most cases attributed to the activating effect that the heteroatoms present in the structures of these $P$-donor ligands exert on the water molecules by $\mathrm{H}$-bonding or deprotonation. By this way, the key nucleophilic attack of water, or the hydroxide anion if deprotonation takes place, on the coordinated nitrile is favored (Figure 1). Most of these "bifunctional catalysts" 13 are able to operate directly in water as the reaction medium, and without the assistance of any acidic or basic additive, showing a wide substrate scope and high tolerance to common functional groups. Studies by Tyler and co-workers revealed also the utility of complexes $\left[\mathrm{RuCl}_{2}\left(\eta^{6}-p\right.\right.$-cymene $\left.)\left\{\mathrm{P}\left(\mathrm{NMe}_{2}\right)_{3}\right\}\right]$ and $\left[\mathrm{RuCl}_{2}\left(\eta^{6}-p\right.\right.$-cymene $\left.)\left(\mathrm{PMe}_{2} \mathrm{OH}\right)\right]$ to promote the challenging hydration of $\alpha$ hydroxynitriles (cyanohydrins) into the corresponding $\alpha$-hydroxyamides. ${ }^{10 \mathrm{c}, \mathrm{f}, 11 \mathrm{~b}} \mathrm{~A}$ extremely low reactivity is usually observed with this particular type of nitriles due to the poisoning of the catalysts by cyanide, a species that is generated in solution by partial decomposition of the cyanohydrins. ${ }^{14}$
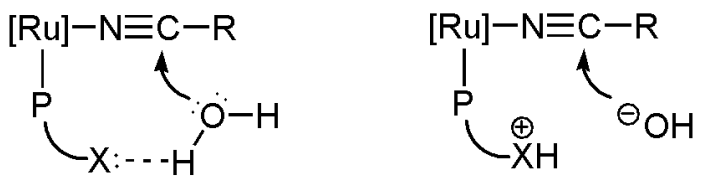

$X=N, O, S$

Figure 1. Cooperative effects of functionalized phosphines in Ru-catalyzed nitrile hydrations.

All the facts commented above support the exploration of new metal complexes with cooperative phosphine ligands as potential catalysts for nitrile hydration reactions. Rhodium compounds are good candidates for such purposes due to the excellent performances shown by this metal in multitude of catalytic processes. ${ }^{15}$ Our interest in rhodium is also motivated by the few bibliographic precedents on its use for the catalytic hydration of $\mathrm{C} \equiv \mathrm{N}$ bonds. Thus, in addition to some early examples of limited

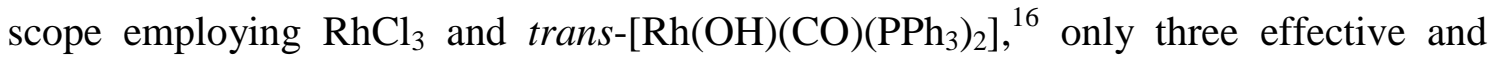
general rhodium-based systems have been described to date in the literature: $(i)$ The 
$\left[\{\mathrm{Rh}(\mu-\mathrm{Cl})(\mathrm{COD})\}_{2}\right] / \mathrm{TPPMS}$ combination $(\mathrm{COD}=1,5$-cyclooctadiene; TPPMS $=$ (meta-sulfonatophenyl)-diphenylphosphine sodium salt), which proved to be active in pure water at $90{ }^{\circ} \mathrm{C}$ under basic conditions (optimal $\left.\mathrm{pH}=11.7\right) .{ }^{17}$ (ii) The $[\{\operatorname{Rh}(\mu$ $\left.\mathrm{OMe})(\mathrm{COD})\}_{2}\right] / \mathrm{PCy}_{3}$ system, which showed a remarkable activity in a ${ }^{\mathrm{i}} \mathrm{PrOH} / \mathrm{H}_{2} \mathrm{O}$ solvent mixture at ambient temperature. ${ }^{18}$ And, (iii) the rhodium(I) complex A (Figure 2), containing a naphthyridyl-substituted $N$-heterocyclic carbene (NHC) ligand, which, in combination with a base $\left(\mathrm{KO}^{\mathrm{t}} \mathrm{Bu}\right)$, was also able to promote the selective hydration of a large number of organonitriles at room temperature in ${ }^{\mathrm{i}} \mathrm{PrOH} / \mathrm{H}_{2} \mathrm{O} .{ }^{19}$ For this latter example, DFT calculations revealed that the bifunctional activation of the water molecule by the naphthyridyl group is one of the key steps in the catalytic cycle (transition state B in Figure 2). To the best of our knowledge, no general rhodium-based catalysts able to operate in pure water under neutral conditions are currently known. That is why, with the aim of filling this gap and on the basis of the previous findings with ruthenium complexes, ${ }^{6-11}$ we decided to carry out a study on the behavior of a series of rhodium(I) derivatives $\left[\mathrm{RhCl}(\mathrm{COD})\left(\mathrm{PR}_{3}\right)\right]$, with potentially cooperative phosphine ligands, in this catalytic transformation. The results from this study are presented herein. Among the different phosphine ligands employed, aminophosphines of general composition $\mathrm{P}\left(\mathrm{NR}_{2}\right)_{3}$ were found to be particularly useful in the development of catalytic systems with high activity.

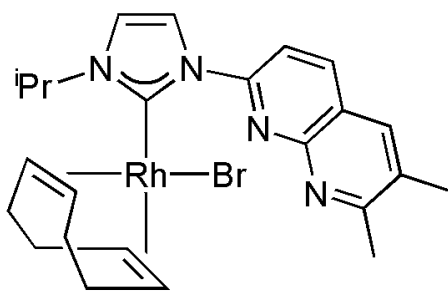

(A)

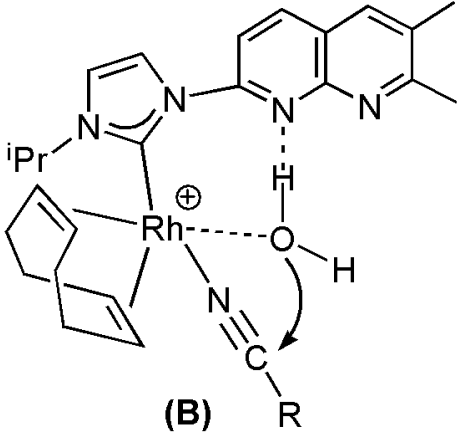

(B)

Figure 2. Structure of the Rh(I)-NHC complex A and the transition state $\mathbf{B}$.

\section{Results and Discussion}

Our research began with the preparation of a diverse family of square-planar $\left[\mathrm{RhCl}(\mathrm{COD})\left(\mathrm{PR}_{3}\right)\right]$ complexes 3a-l through the treatment of dimer $\left[\{\mathrm{Rh}(\mu-\mathrm{Cl})(\mathrm{COD})\}_{2}\right]$ 
(1) with two equivalents of the corresponding monodentate $P$-donor ligand (Scheme 1). Thus, in addition to triphenylphosphine (2a) which was only included for comparative purposes, the following potentially cooperative phosphines were employed: the pyridylphosphines $\mathbf{2 b - d}$, the cage-like water soluble ligands PTA (2e) and DAPTA (2f), the aminophosphines $\mathbf{2 g - k}$, and the trihydrazinophosphaadamantane derivative $\mathbf{2 l}$ (THPA). Most of these ligands have previously demonstrated their usefulness in the development of highly effective ruthenium catalysts for nitrile hydration processes. ${ }^{6,9,10}$ The chloride bridges cleavage reactions of dimer $\mathbf{1}$ with phosphines $\mathbf{2 a - l}$ proceeded quickly and cleanly in tetrahydrofuran at room temperature, affording complexes $\left[\mathrm{RhCl}(\mathrm{COD})\left(\mathrm{PR}_{3}\right)\right](\mathbf{3 a}-\mathbf{l})$ which were isolated as yellow solids (oily material in the case of 3i) in high yields (80-94\%).<smiles>ClP1(Cl)(C2CC3CCC2C3)C2CC3CC(C2)C31</smiles>

1

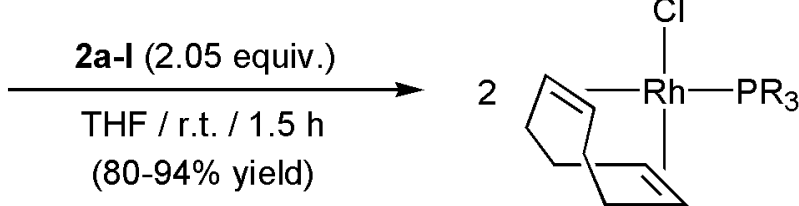

3a-I

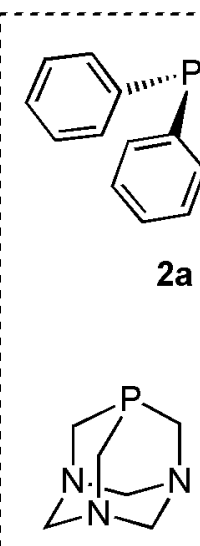

$2 e$<smiles>CC(=O)N1CN2CN(C(C)=O)CP(C2)C1</smiles>

$2 f$<smiles>[R]c1ccnc(P(c2ccccc2)c2ccccc2)c1</smiles>

$\mathrm{R}=\mathrm{H}(\mathbf{2 b}), \mathrm{NMe}_{2}$ (2c)

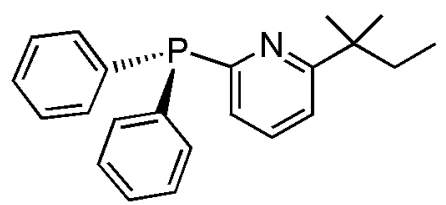

2d

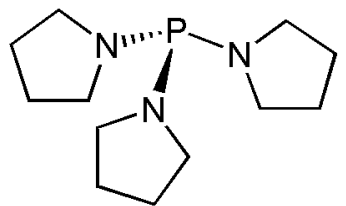

2j<smiles>CN(C)P(c1ccccc1)c1ccccc1</smiles>

$2 \mathrm{~g}$<smiles>[R20]N[R]([R20])[R2]</smiles>
$\mathrm{R}=\mathrm{Me}(\mathbf{2 h})$, Et (2i)

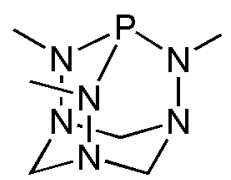

2l

Scheme 1. Synthesis of the mononuclear $\mathrm{Rh}(\mathrm{I})$ complexes $\left[\mathrm{RhCl}(\mathrm{COD})\left(\mathrm{PR}_{3}\right)\right](\mathbf{3 a - l})$. 
Compounds $\left[\mathrm{RhCl}(\mathrm{COD})\left(\mathrm{PPh}_{3}\right)\right] \quad(\mathbf{3 a}),{ }^{20} \quad\left[\mathrm{RhCl}(\mathrm{COD})\left(\mathrm{PPh}_{2} \mathrm{py}\right)\right] \quad(\mathbf{3 b})^{21}$ and $[\mathrm{RhCl}(\mathrm{COD})(\mathrm{THPA})](\mathbf{3 l})^{22}$ have been previously described in the literature. ${ }^{23}$ The rest of complexes were fully characterized by means of elemental analyses, IR and multinuclear NMR spectroscopy $\left({ }^{31} \mathrm{P}\left\{{ }^{1} \mathrm{H}\right\},{ }^{1} \mathrm{H}\right.$ and $\left.{ }^{13} \mathrm{C}\left\{{ }^{1} \mathrm{H}\right\}\right)$, all data being fully consistent with the proposed formulations (details are given in the Experimental Section). In particular, their ${ }^{31} \mathrm{P}\left\{{ }^{1} \mathrm{H}\right\}$ NMR spectra confirmed the coordination of the phosphines to the metal centre, as doublet resonances due to $\mathrm{P}-\mathrm{Rh}$ coupling were observed at chemical shifts different from those found for the free ligands (Table 1). The values of the ${ }^{1} J\left({ }^{31} \mathrm{P},{ }^{103} \mathrm{Rh}\right)$ coupling constants are a direct indicator for the strength of the P-Rh bonds. ${ }^{23 b, c}$ In accord, the measured values for complexes 3a-l showed the expected increase with the $\pi$-accepting nature of the $\mathrm{PR}_{3}$ ligands, ${ }^{23 \mathrm{~b}, \mathrm{c}, 24}$ the highest ${ }^{1} J\left({ }^{31} \mathrm{P},{ }^{103} \mathrm{Rh}\right)$ value of $231.9 \mathrm{~Hz}$ being observed for $\left[\mathrm{RhCl}(\mathrm{COD})\left\{\mathrm{P}(N \text {-pyrrolyl })_{3}\right\}\right]$ (3k). ${ }^{25}$ The ${ }^{1} \mathrm{H}$ and ${ }^{13} \mathrm{C}\left\{{ }^{1} \mathrm{H}\right\}$ NMR spectra of the novel derivatives $\mathbf{3 c}-\mathbf{3 k}$ were also in agreement with the proposed structures, showing the expected resonances for the corresponding phosphine ligand and the $\eta^{4}$-coordinated 1,5-cyclooctadiene unit. For the latter, the expected two sets of resonances for the chemically inequivalent olefinic protons and carbons were observed.

Table 1. ${ }^{31} \mathrm{P}\left\{{ }^{1} \mathrm{H}\right\}$ NMR data for ligands $\mathbf{2 a - 1}$ and complexes 3a-l. ${ }^{a}$

\begin{tabular}{lllll}
\hline Ligand & $\delta_{\mathrm{P}}(\mathrm{ppm})$ & Complex & $\delta_{\mathrm{P}}(\mathrm{ppm})$ & ${ }^{1} J_{\mathrm{RhP}}(\mathrm{Hz})$ \\
\hline $\mathbf{2 a}$ & -6.0 & $\mathbf{3 a}^{b}$ & 31.4 & 152.0 \\
$\mathbf{2 b}$ & -3.5 & $\mathbf{3 b}$ & 28.5 & 150.6 \\
$\mathbf{2 c}$ & -2.0 & $\mathbf{3 c}^{c}$ & 30.9 & 149.6 \\
$\mathbf{2 d}$ & -3.6 & $\mathbf{3 d}$ & 29.4 & 151.8 \\
$\mathbf{2 e}$ & -101.9 & $\mathbf{3 e}$ & -52.9 & 149.4 \\
$\mathbf{2 f}$ & -78.8 & $\mathbf{3 f}$ & -29.2 & 153.1 \\
$\mathbf{2 g}$ & 66.0 & $\mathbf{3 g}$ & 79.0 & 159.7 \\
$\mathbf{2 h}$ & 123.0 & $\mathbf{3 h}$ & 109.3 & 194.4 \\
$\mathbf{2 i}$ & 117.1 & $\mathbf{3 i}$ & 113.0 & 196.3 \\
$\mathbf{2 j}$ & 104.9 & $\mathbf{3 j}^{b}$ & 90.3 & 192.5 \\
$\mathbf{2} \mathbf{k}^{d}$ & 79.6 & $\mathbf{3 k}$ & 90.3 & 231.9 \\
$\mathbf{2 l}$ & 101.8 & $\mathbf{3 l}$ & 116.6 & 199.9 \\
\hline
\end{tabular}

${ }^{a}$ Unless otherwise stated the NMR spectra were recorded in $\mathrm{CDCl}_{3} \cdot{ }^{b}$ Spectrum recorded in $\mathrm{C}_{6} \mathrm{D}_{6} \cdot{ }^{c}$ Spectrum recorded in $\mathrm{CD}_{2} \mathrm{Cl}_{2} \cdot{ }^{d}$ Spectrum recorded in toluene- $d_{8}$. 
Taking into account the good results previously obtained with the dinuclear $\mathrm{Ru}(\mathrm{IV})$ complex $\left[\left\{\mathrm{RuCl}_{2}\left(\eta^{3}: \eta^{3}-\mathrm{C}_{10} \mathrm{H}_{16}\right)\right\}_{2}(\mu\right.$-THDP $\left.)\right]\left(\mathrm{C}_{10} \mathrm{H}_{16}=\right.$ 2,7-dimethylocta-2,6diene-1,8-diyl; THDP $=$ tris(1,2-dimethylhydrazino)diphosphine (2m)), ${ }^{9 \mathrm{~b}}$ we also considered the use of the analogous dirhodium(I) derivative $\left[\{\mathrm{RhCl}(\mathrm{COD})\}_{2}(\mu\right.$-THDP $\left.)\right]$ (3m) in our study. This dinuclear species was synthesized in 95\% yield through a known procedure formerly described by us (Scheme 2$){ }^{26,27}$

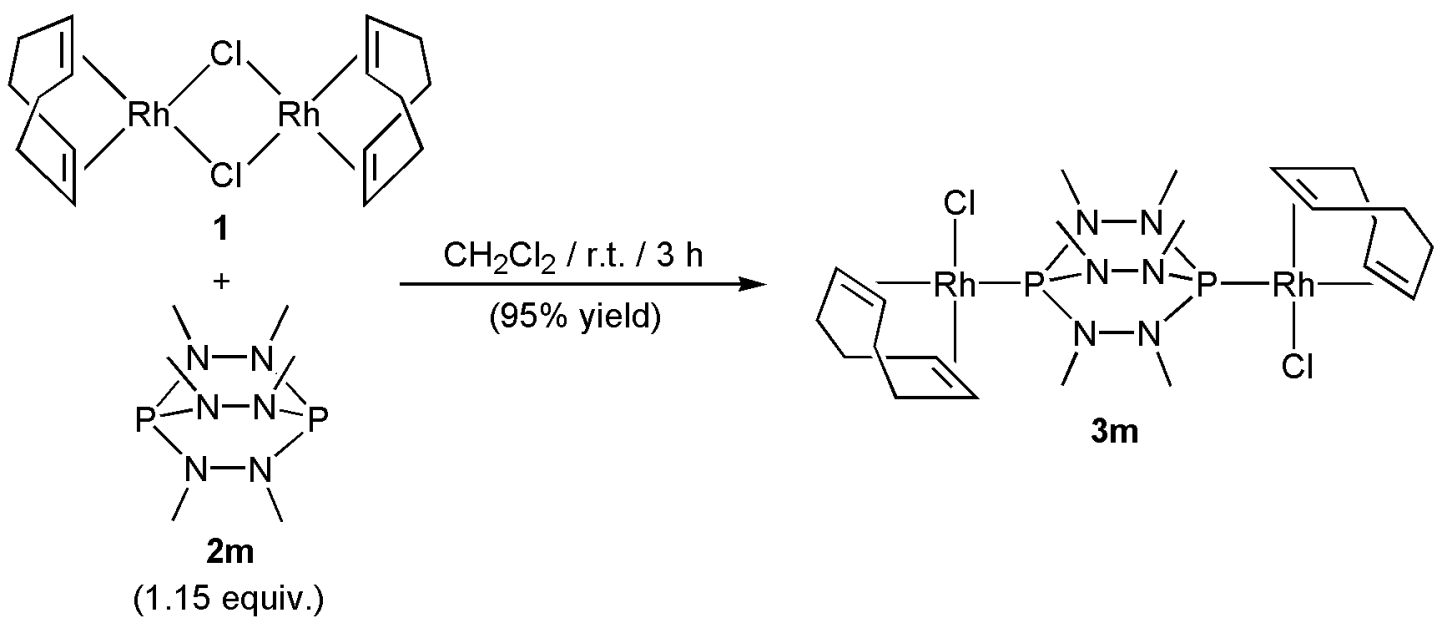

Scheme 2. Synthesis of the dinuclear $\mathrm{Rh}(\mathrm{I})$ complex $\left[\{\mathrm{RhCl}(\mathrm{COD})\}_{2}(\mu\right.$-THDP $\left.)\right](\mathbf{3 m})$.

The catalytic potential of the $\mathrm{Rh}(\mathrm{I})$ complexes 3a-m for nitrile hydration reactions was then investigated using benzonitrile (4a) as model substrate. In a typical experiment, the corresponding complex (5 mol\% of $\mathrm{Rh}$ ) was added under $\mathrm{N}_{2}$ atmosphere to a $0.33 \mathrm{M}$ aqueous solution of $\mathbf{4 a}$, and the mixture heated in an oil bath at $100{ }^{\circ} \mathrm{C}$ for $7 \mathrm{~h}$. The results obtained are collected in Table 2 . Under the neutral conditions employed, the dimeric precursor $\left[\{\mathrm{Rh}(\mu-\mathrm{Cl})(\mathrm{COD})\}_{2}\right]$ (1) and the triphenylphosphine complex $\left[\mathrm{RhCl}(\mathrm{COD})\left(\mathrm{PPh}_{3}\right)\right]$ (3a) were nearly inactive in the hydration process (entries 1-2), delivering benzamide (5a) in only 2-4\% yield as determined by gas chromatography (GC). ${ }^{28}$ Slight improvements were observed when the reaction was performed with the pyridyl-phosphine complexes $\left[\mathrm{RhCl}(\mathrm{COD})\left(\mathrm{PPh}_{2}\right.\right.$ py) $](\mathbf{3 b})$ and $\left[\mathrm{RhCl}(\mathrm{COD})\left\{\mathrm{PPh}_{2}(\right.\right.$ py-4-NMe 2$\left.\left.)\right\}\right](\mathbf{3 c})$, although yields were still unsatisfactory (entries 3-4). A reason for the low catalytic activity shown by 3b-c might be related with the chelation of the ligands to rhodium, that would compete with the activation of the water molecule by hydrogen bonding with the pyridyl nitrogen 
atom. ${ }^{29,30}$ However, we must note that the use of the bulkier pyridyl-phosphine $\mathrm{PPh}_{2}$ (py6-tert-amyl), for which the chelation process would be sterically disfavoured, did not result in any improvement (entry 5). ${ }^{31}$ All these facts indicate that cooperative effects of this class of ligands are negligible within the $\left[\mathrm{RhCl}(\mathrm{COD})\left(\mathrm{PR}_{3}\right)\right]$ series. We would like to stress in this point that solubility grounds (compounds 3a-d are not soluble in water at r.t.) are not behind the poor catalytic activities observed, since similar low yields were also achieved performing the reactions in a ${ }^{\mathrm{i}} \mathrm{PrOH} / \mathrm{H}_{2} \mathrm{O}(1: 1 \mathrm{v} / \mathrm{v})$ mixture. Moreover, the highly water-soluble complexes [RhCl(COD)(PTA)] (3e) and [ $\mathrm{RhCl}(\mathrm{COD})(\mathrm{DAPTA})]$ (3f) proved to be almost inactive in the hydration process (entries 6 and 7).

Table 2. Hydration of Benzonitrile (4a) into Benzamide (5a) Catalyzed by the Rhodium(I) Complexes $\mathbf{1}$ and 3a-n in Water. ${ }^{a}$

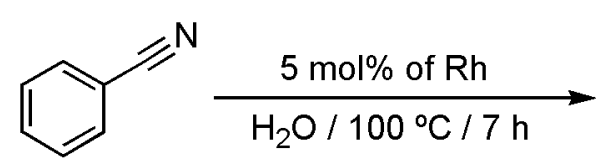

$4 a$<smiles>NC(=O)c1ccccc1</smiles>

$5 a$

\begin{tabular}{|c|c|c|c|}
\hline Entry & Conditions & Yield $(\%)^{b}$ & TOF $\left(h^{-1}\right)^{c}$ \\
\hline 1 & {$\left[\{\mathrm{Rh}(\mu-\mathrm{Cl})(\mathrm{COD})\}_{2}\right](\mathbf{1})$} & 4 & 0.1 \\
\hline 2 & {$\left[\mathrm{RhCl}(\mathrm{COD})\left(\mathrm{PPh}_{3}\right)\right](\mathbf{3 a})$} & 2 & $<0.1$ \\
\hline 3 & {$\left[\mathrm{RhCl}(\mathrm{COD})\left(\mathrm{PPh}_{2} \mathrm{py}\right)\right](\mathbf{3 b})$} & 10 & 0.3 \\
\hline 4 & {$\left[\mathrm{RhCl}(\mathrm{COD})\left\{\mathrm{PPh}_{2}\left(\mathrm{py}-4-\mathrm{NMe}_{2}\right)\right\}\right](\mathbf{3 c})$} & 21 & 0.6 \\
\hline 5 & {$\left[\mathrm{RhCl}(\mathrm{COD})\left\{\mathrm{PPh}_{2}(\right.\right.$ py-6-tert-amyl $\left.\left.)\right\}\right](\mathbf{3 d})$} & 3 & $<0.1$ \\
\hline 6 & {$[\mathrm{RhCl}(\mathrm{COD})(\mathrm{PTA})](\mathbf{3 e})$} & 4 & 0.1 \\
\hline 7 & {$[\mathrm{RhCl}(\mathrm{COD})(\mathrm{DAPTA})](\mathbf{3 f})$} & 6 & 0.2 \\
\hline 8 & {$\left[\mathrm{RhCl}(\mathrm{COD})\left\{\mathrm{PPh}_{2}\left(\mathrm{NMe}_{2}\right)\right\}\right](\mathbf{3 g})$} & 54 & 1.5 \\
\hline 9 & {$\left[\mathrm{RhCl}(\mathrm{COD})\left\{\mathrm{P}\left(\mathrm{NMe}_{2}\right)_{3}\right\}\right](\mathbf{3 h})$} & 87 & 2.5 \\
\hline 10 & {$\left[\mathrm{RhCl}(\mathrm{COD})\left\{\mathrm{P}\left(\mathrm{NEt}_{2}\right)_{3}\right\}\right](\mathbf{3 i})$} & 24 & 0.7 \\
\hline 11 & {$\left[\mathrm{RhCl}(\mathrm{COD})\left\{\mathrm{P}(N \text {-pyrrolidinyl })_{3}\right\}\right](\mathbf{3 j})$} & 78 & 2.2 \\
\hline 12 & {$\left[\mathrm{RhCl}(\mathrm{COD})\left\{\mathrm{P}(N \text {-pyrrolyl })_{3}\right\}\right](\mathbf{3 k})$} & traces & --- \\
\hline 13 & {$[\mathrm{RhCl}(\mathrm{COD})(\mathrm{THPA})](\mathbf{3 I})$} & 78 & 2.2 \\
\hline 14 & {$\left[\{\mathrm{RhCl}(\mathrm{COD})\}_{2}(\mu-\mathrm{THDP})\right](\mathbf{3 m})$} & 73 & 2.1 \\
\hline 15 & {$\left[\mathrm{RhCl}(\mathrm{COD})\left\{\mathrm{P}(\mathrm{OMe})_{3}\right\}\right](\mathbf{3 n})$} & 12 & 0.3 \\
\hline
\end{tabular}


${ }^{a}$ Reactions performed under a $\mathrm{N}_{2}$ atmosphere at $100{ }^{\circ} \mathrm{C}$ using $1 \mathrm{mmol}$ of benzonitrile $(0.33 \mathrm{M}$ in water). Substrate/Rh ratio: 100/5. ${ }^{b}$ Yields determined by GC (uncorrected GC areas). ${ }^{c}$ Turnover frequencies ((mol product/mol Rh)/time).

Fortunately, much better results were obtained with the rhodium complexes that contain auxiliary phosphine ligands with direct P-N bonds. Thus, the substitution of $\mathrm{PPh}_{3}$ by $\mathrm{PPh}_{2} \mathrm{NMe}_{2}$ allowed to increase the benzamide (5a) yield to $54 \%$ (entry $8 \mathrm{vs}$ entry 2). Further improvements were reached with the tris(amino)phosphine-based complexes $\left[\mathrm{RhCl}(\mathrm{COD})\left\{\mathrm{P}\left(\mathrm{NMe}_{2}\right)_{3}\right\}\right] \quad(\mathbf{3 h}) \quad($ entry 9$)$ and $[\mathrm{RhCl}(\mathrm{COD})\{\mathrm{P}(N-$ pyrrolidinyl $\left.\left.)_{3}\right\}\right]$ (3j) (entry 11), and the hydrazinophosphine-based ones $[\mathrm{RhCl}(\mathrm{COD})(\mathrm{THPA})](\mathbf{3 l})$ (entry 13$)$ and $\left[\{\mathrm{RhCl}(\mathrm{COD})\}_{2}(\mu\right.$-THDP)] (3m) (entry 14). All of them were able to generate $\mathbf{5 a}$ in $\geq 73 \%$ GC-yield after $7 \mathrm{~h}$ of heating, with $\left[\mathrm{RhCl}(\mathrm{COD})\left\{\mathrm{P}\left(\mathrm{NMe}_{2}\right)_{3}\right\}\right]$ (3h) showing the best performance $\left(87 \%\right.$ yield; TOF $=2.5 \mathrm{~h}^{-}$ 1; entry 9). As previously proposed for the ruthenium(II) complexes $\left[\mathrm{RuCl}_{2}\left(\eta^{6}-\right.\right.$ arene) $\left.\left\{\mathrm{P}\left(\mathrm{NMe}_{2}\right)_{3}\right\}\right],{ }^{10 \mathrm{f}}$ the enhanced activities of these systems most probably relies with the effective activation of the incoming water molecule by $\mathrm{H}$-bonding during its nucleophilic attack to the coordinated nitrile (Figure 3).

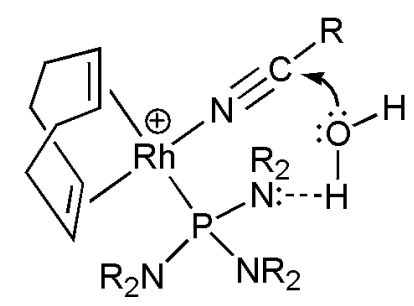

Figure 3. The proposed activating effect of the amino- and hydrazino-phosphine ligands.

The marked differences in activity observed between complexes $\left[\mathrm{RhCl}(\mathrm{COD})\left\{\mathrm{P}(N \text {-pyrrolidinyl })_{3}\right\}\right](\mathbf{3 j})$ and $\left[\mathrm{RhCl}(\mathrm{COD})\left\{\mathrm{P}(N \text {-pyrrolyl })_{3}\right\}\right](\mathbf{3 k})$ seem to support this proposal. Thus, while complex $\left[\operatorname{RhCl}(\mathrm{COD})\left\{\mathrm{P}(N \text {-pyrrolidinyl })_{3}\right\}\right](\mathbf{3 j})$, in which the lone pairs of the nitrogen atoms are available to establish H-bonds with water, showed a respectable activity (entry 11$)$, complex $\left[\mathrm{RhCl}(\mathrm{COD})\left\{\mathrm{P}(N \text {-pyrrolyl) })_{3}\right\}\right]$ (3k) resulted completely inactive (entry 12), due to the aromatic delocalization of the nitrogen lone pairs into the pyrrole rings (resonance structures are shown in Figure 4). ${ }^{32}$ Full evidence of the aromaticity of the pyrrole rings in $\mathbf{3 k}$ was gained through its computed electrostatic potential map (included along with that of $\mathbf{3 j}$ in the Supporting 
Information). In addition, we have also theoretically studied (DFT calculations) the relative basicity of the nitrogen atoms of the pyrrolidine/pyrrole fragments in complexes $\left[\mathrm{RhCl}(\mathrm{COD})\left\{\mathrm{P}(\mathrm{N}-\text { pyrrolidinyl })_{3}\right\}\right] \quad(\mathbf{3 j})$ and $\left[\mathrm{RhCl}(\mathrm{COD})\left\{\mathrm{P}(\mathrm{N}-\text { pyrrolyl })_{3}\right\}\right] \quad$ (3k). Protonation of the pyrrolidine $\mathrm{N}$ atom in $\mathbf{3} \mathbf{j}$ was found to be favored by $37.12 \mathrm{kcal} / \mathrm{mol}$ with respect to that of the pyrrole moiety in $\mathbf{3 k}$. This fact clearly indicates that the $\mathrm{N}$ atoms of $\mathrm{P}(\mathrm{N} \text {-pyrrolidinyl })_{3}$ are much more basic than those of $\mathrm{P}(\mathrm{N} \text {-pyrrolyl })_{3}$, and therefore more prone to establish H-bonds with water (details are included in the Supporting Information). ${ }^{33}$

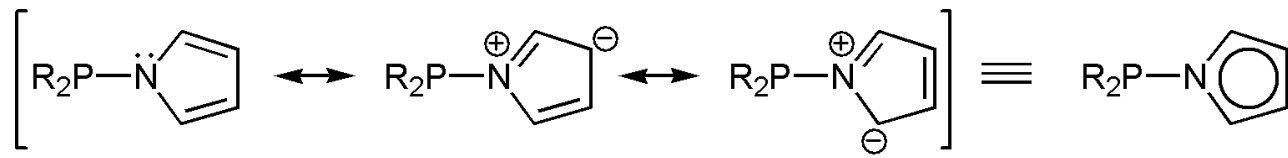

Figure 4. Resonance structures for $N$-pyrrolyl phosphine ligands.

During this initial study, a striking result was found with complex $\left[\mathrm{RhCl}(\mathrm{COD})\left\{\mathrm{P}\left(\mathrm{NEt}_{2}\right)_{3}\right\}\right]$ (3i), which showed a much lower activity (24\% GC-yield; entry 10) than that of its peers $\mathbf{3 h}, \mathbf{j}, \mathbf{l}, \mathbf{m}$ ( $\geq 73 \%$ GC-yield; entries 9, 11, 13 and 14). We initially thought that this could be due to the larger size of the tris(diethylamino)phosphine ligand 2i. However, the differences between the cone angle ${ }^{34}$ of $\mathrm{P}\left(\mathrm{NEt}_{2}\right)_{3}\left(\mathbf{2 i} ; 174.0^{\circ}\right)$ and those of $\mathrm{P}\left(\mathrm{NMe}_{2}\right)_{3}\left(\mathbf{2 h} ; 167.9^{\circ}\right), \mathrm{P}(N \text {-pyrrolidinyl })_{3}$ $\left(\mathbf{2 j} ; 169.8^{\circ}\right)$, THPA $\left(2 \mathbf{2} ; 165.0^{\circ}\right)$ and THDP $\left(\mathbf{2 m} ; 165.9^{\circ}\right)$, all calculated following the mathematical procedure recently described by Allen and co-workers from the DFToptimized structures of complexes $\mathbf{3 h}-\mathbf{j}, \mathbf{l}, \mathbf{m}$ (included in the Supporting Information file), ${ }^{35}$ seems to be not significant enough to explain the remarkably lower efficiency of $\left[\mathrm{RhCl}(\mathrm{COD})\left\{\mathrm{P}\left(\mathrm{NEt}_{2}\right)_{3}\right\}\right](\mathbf{3 i}) .{ }^{36}$ Further studies indicated that stability grounds are more probably behind this discrepancy. In favour of this hypothesis is the fact that, while complexes $\left[\mathrm{RhCl}(\mathrm{COD})\left\{\mathrm{P}\left(\mathrm{NMe}_{2}\right)_{3}\right\}\right](\mathbf{3 h})$ and $\left[\mathrm{RhCl}(\mathrm{COD})\left\{\mathrm{P}(N \text {-pyrrolidinyl })_{3}\right\}\right](\mathbf{3 j})$ are perfectly stable in solution, complex $\left[\mathrm{RhCl}(\mathrm{COD})\left\{\mathrm{P}\left(\mathrm{NEt}_{2}\right)_{3}\right\}\right](\mathbf{3 i})$ evolves in polar media into a mixture of uncharacterized products, as assessed by ${ }^{31} \mathrm{P}\left\{{ }^{1} \mathrm{H}\right\}$ and ${ }^{1} \mathrm{H} \mathrm{NMR}$ spectroscopy $\left(\mathrm{CD}_{3} \mathrm{CN}\right.$ and $\mathrm{CD}_{3} \mathrm{NO}_{2}$ solutions). The flexibility associated with the ethyl units of the ligand $\mathrm{P}\left(\mathrm{NEt}_{2}\right)_{3}$, which allows the approach of the methyl groups to the $\mathrm{Rh}(\mathrm{I})$ center, could lead to the oxidative $\mathrm{C}-\mathrm{H}$ addition of these groups to the metal and hence the observed instability. ${ }^{37}$ 
On the other hand, analogously to what was previously observed with ruthenium catalysts, ${ }^{10 \mathrm{f}}$ replacement of the tris(amino)phosphine ligands by $\mathrm{P}(\mathrm{OMe})_{3}$ led to a much less active catalyst, i.e. $\left[\mathrm{RhCl}(\mathrm{COD})\left\{\mathrm{P}(\mathrm{OMe})_{3}\right\}\right]$ (3n) (entry 15), pointing out the key role played by the $\mathrm{P}-\mathrm{N}$ units, which seems to establish stronger $\mathrm{H}$-bonds with water in comparison with the $\mathrm{P}-\mathrm{O}$ ones.

As commented in the introduction of this article, most of the known rhodium catalysts usually require of basic reaction conditions to hydrate $\mathrm{C} \equiv \mathrm{N}$ bonds in an effective manner. This raised the question of whether the addition of a base could improve the activity of our catalysts. To answer this question we conducted the hydration of benzonitrile (4a) with the most active complex $\left[\mathrm{RhCl}(\mathrm{COD})\left\{\mathrm{P}\left(\mathrm{NMe}_{2}\right)_{3}\right\}\right]$ (3h) $(5 \mathrm{~mol} \%)$ in the presence of variable amounts of $\mathrm{KO}^{\mathrm{t}} \mathrm{Bu}$ (from 1 to $5 \mathrm{~mol} \%$; i.e. from 0.2 to 1 equiv. per Rh atom). As shown in Figure 5, slight improvements in activity where observed in the presence of 1-3 mol\% of $\mathrm{KO}^{\mathrm{t}} \mathrm{Bu}$, but a drastic drop occurred when a larger amount of base was added (4-5 mol\% of $\left.\mathrm{KO}^{\mathrm{t}} \mathrm{Bu}\right) . \mathrm{pH}$ measurements on these solutions showed a significant increase in the basicity of the reaction medium (from 7.9 in the absence of $\mathrm{KO}^{\mathrm{t}} \mathrm{Bu}$ to 12.1 in the presence of $5 \mathrm{~mol} \%$ of $\left.\mathrm{KO}^{\mathrm{t}} \mathrm{Bu}\right)$, which is accompanied with a rapid decomposition of $\mathbf{3 h}\left({ }^{31} \mathrm{P}\left\{{ }^{1} \mathrm{H}\right\}\right.$ NMR measurements). The sudden change in activity observed in the presence of $4-5 \mathrm{~mol} \%$ of $\mathrm{KO}^{\mathrm{t}} \mathrm{Bu}$ seems therefore associated with the low stability complex $\left[\mathrm{RhCl}(\mathrm{COD})\left\{\mathrm{P}\left(\mathrm{NMe}_{2}\right)_{3}\right\}\right](\mathbf{3 h})$ in highly basic media. ${ }^{38}$ Similar observations were made employing the related complex $\mathbf{3 j}$. Since the addition of a base did not result in significant improvements, we decided to study the scope of the catalytic reaction with $\left[\mathrm{RhCl}(\mathrm{COD})\left\{\mathrm{P}\left(\mathrm{NMe}_{2}\right)_{3}\right\}\right](\mathbf{3 h})$ under neutral conditions. To this end, a variety of nitriles were subjected to the action of $\mathbf{3 h}(5 \mathrm{~mol} \%)$ in pure water $(0.33 \mathrm{M}$ solutions $)$ at $100{ }^{\circ} \mathrm{C}$. Selected results are collected in Table 3. 


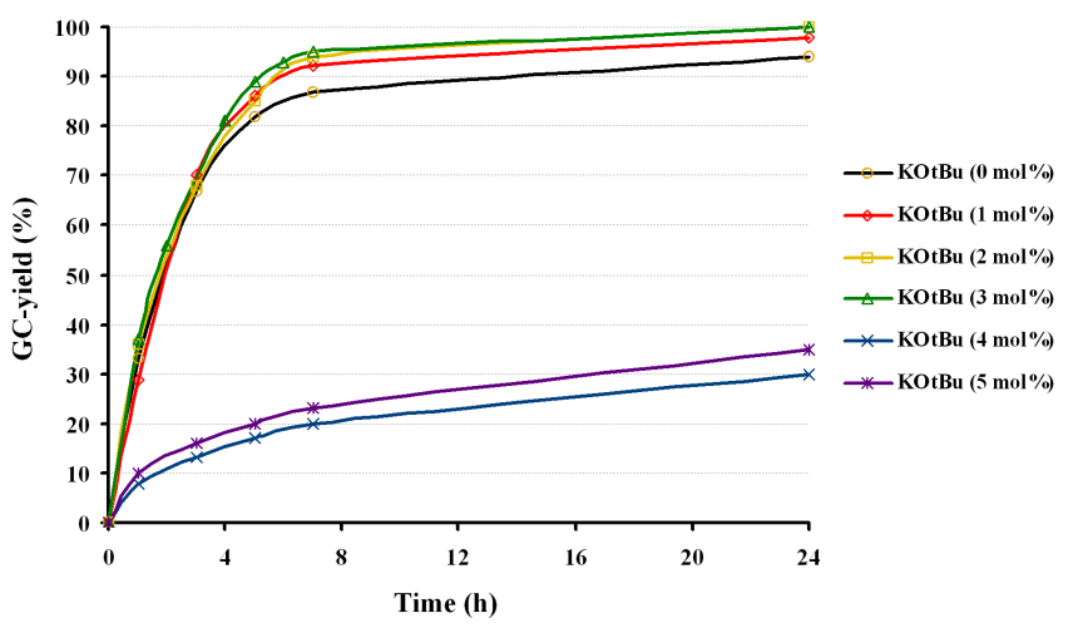

Figure 5. Catalytic hydration of $\mathbf{4 a}$ into $5 \mathbf{a}$ using the $\mathrm{Rh}(\mathrm{I})$ complex $\left[\mathrm{RhCl}(\mathrm{COD})\left\{\mathrm{P}\left(\mathrm{NMe}_{2}\right)_{3}\right\}\right]$ $(3 \mathbf{h})$ in the presence or absence of $\mathrm{KO}^{\mathrm{t}} \mathrm{Bu}$. Conditions: reactions performed under $\mathrm{N}_{2}$ atmosphere at $100^{\circ} \mathrm{C}$ using $1 \mathrm{mmol}$ of $\mathbf{4 a}, 0.05 \mathrm{mmol}$ of $\mathbf{3 h}(5 \mathrm{~mol} \%)$ and $3 \mathrm{~mL}$ of water.

As observed for benzonitrile (4a), which was converted into benzamide (5a) in 94\% GC-yield after $24 \mathrm{~h}$ of heating (entry 1), other aromatic nitriles $\mathbf{4 b}$-h could be transformed into the corresponding primary amides $\mathbf{5 b}$-h in high yields $(\geq 79 \%$ GCyield) after 7-24 h (entries 2-8). A slight influence of the electronic properties of the aryl rings was observed, with those substrates containing electron-donating groups showing in general a lower reactivity (e.g. entry 8 vs 6). Substitution in ortho position also resulted in a less efficient hydration (entry 3 vs 4). Remarkably, in no case traces of the corresponding benzoic acids were detected by GC in the crude reaction mixtures. Complex $\left[\mathrm{RhCl}(\mathrm{COD})\left\{\mathrm{P}\left(\mathrm{NMe}_{2}\right)_{3}\right\}\right]$ (3h) was particularly effective with heteroaromatic nitriles (entries 9-17). In addition, for this particular class of substrates, marked differences in activity were observed depending on the relative position of the heteroatom and the $\mathrm{C} \equiv \mathrm{N}$ unit. Thus, while 2-cyanopyridine (4i) and 4-cyanopyridine (4k) were almost quantitatively converted into picolinamide (5i) and isonicotinamide (5k), respectively, after only 2-3 h of heating (entries 9 and 11), a much longer reaction time $(24 \mathrm{~h})$ was needed to generate nicotinamide $(\mathbf{5 j})$ from 3 -cyanopyridine $(\mathbf{4 j})$ in high yield (entry 10). Resonance effects could be responsible for the different reactivity observed since in $\mathbf{4} \mathbf{j}$ the nitrile carbon has a reduced electrophilicity (negative charges always located on the carbon atoms of the py ring $v s \mathrm{~N}$ atoms in the case of $4 \mathbf{i}$ and $\mathbf{4 k}$ ), and therefore the nucleophilic addition of water at this position is disfavored. 
Table 3. Catalytic Hydration of Nitriles into Amides in Water Using $\left[\mathrm{RhCl}(\mathrm{COD})\left\{\mathrm{P}\left(\mathrm{NMe}_{2}\right)_{3}\right\}\right](\mathbf{3 h})$ as Catalyst. ${ }^{a}$

\begin{tabular}{|c|c|c|c|c|}
\hline & $\mathrm{R}=\mathrm{N}$ & $\frac{3 \mathrm{~h}(5 \mathrm{~mol} \%)}{\mathrm{H}_{2} \mathrm{O} / 100^{\circ} \mathrm{C}}$ & $\underbrace{\mathrm{O}}_{5 a-x} \mathrm{NH}_{2}$ & \\
\hline Entry & Substrate & Time (h) & Yield $(\%)^{b}$ & $\operatorname{TOF}\left(\mathrm{h}^{-1}\right)^{c}$ \\
\hline 1 & $\mathrm{R}=\mathrm{Ph}(\mathbf{4 a})$ & 24 & 5a; $94(91)$ & 0.8 \\
\hline 2 & $\mathrm{R}=\mathrm{C}_{6} \mathrm{~F}_{5}(\mathbf{4 b})$ & 24 & $\mathbf{5 b} ; 96(88)$ & 0.8 \\
\hline 3 & $\mathrm{R}=2-\mathrm{C}_{6} \mathrm{H}_{4} \mathrm{~F}(\mathbf{4 c})$ & 24 & $\mathbf{5 c} ; 79(55)$ & 0.6 \\
\hline 4 & $\mathrm{R}=4-\mathrm{C}_{6} \mathrm{H}_{4} \mathrm{~F}(\mathbf{4 d})$ & 24 & 5d; $96(79)$ & 0.8 \\
\hline 5 & $\mathrm{R}=4-\mathrm{C}_{6} \mathrm{H}_{4} \mathrm{Cl}(\mathbf{4 e})$ & 24 & 5e; $94(91)$ & 0.8 \\
\hline 6 & $\mathrm{R}=3-\mathrm{C}_{6} \mathrm{H}_{4} \mathrm{NO}_{2}(\mathbf{4 f})$ & 7 & $\mathbf{5 f} ; 99(92)$ & 2.8 \\
\hline 7 & $\mathrm{R}=4-\mathrm{C}_{6} \mathrm{H}_{4} \mathrm{Me}(\mathbf{4 g})$ & 24 & $\mathbf{5 g} ; 87(73)$ & 0.7 \\
\hline 8 & $\mathrm{R}=3-\mathrm{C}_{6} \mathrm{H}_{4} \mathrm{OMe}(\mathbf{4 h})$ & 24 & $\mathbf{5 h} ; 92(71)$ & 0.7 \\
\hline 9 & $\mathrm{R}=2-$ Pyridyl (4i) & 2 & $\mathbf{5 i} ; 99(87)$ & 9.9 \\
\hline 10 & $\mathrm{R}=3$-Pyridyl $(\mathbf{4} \mathbf{j})$ & 24 & $\mathbf{5 j} ; 90(75)$ & 0.7 \\
\hline 11 & $\mathrm{R}=4-$ Pyridyl (4k) & 3 & $\mathbf{5 k} ; 98(84)$ & 6.5 \\
\hline 12 & $\mathrm{R}=2$-Pyrimidyl (4I) & 1 & 5l; 99 (89) & 19.8 \\
\hline 13 & $\mathrm{R}=$ Pyrazyl (4m) & 1.5 & 5m; $96(82)$ & 12.8 \\
\hline 14 & $R=2-$ Thienyl $(\mathbf{4 n})$ & 2 & 5n; $99(87)$ & 9.9 \\
\hline 15 & $\mathrm{R}=3$-Thienyl (4o) & 24 & 5o; $86(56)$ & 0.7 \\
\hline 16 & $\mathrm{R}=5-\mathrm{Me}-2$-furyl $(\mathbf{4 p})$ & 2 & $\mathbf{5 p} ; 99(90)$ & 9.9 \\
\hline 17 & $\mathrm{R}=3$-Furyl (4q) & 24 & $\mathbf{5 q} ; 96(77)$ & 0.8 \\
\hline 18 & $\mathrm{R}=n-\mathrm{C}_{6} \mathrm{H}_{13}(\mathbf{4 r})$ & 24 & $\mathbf{5 r} ; 12$ & 0.1 \\
\hline 19 & $\mathrm{R}=\mathrm{CH}_{3}(\mathbf{4 s})$ & 24 & $5 s ; 5$ & 0.04 \\
\hline 20 & $\mathrm{R}=\mathrm{CH}_{2} \mathrm{Cl}(\mathbf{4 t})$ & 5 & $\mathbf{5 t} ; 95(80)$ & 3.8 \\
\hline 21 & $\mathrm{R}=\mathrm{CCl}_{3}(\mathbf{4 u})$ & 0.5 & $\mathbf{5 u} ; 97$ (79) & 38.8 \\
\hline 22 & $\mathrm{R}=\mathrm{CH}_{2} \mathrm{OPh}(\mathbf{4} \mathbf{v})$ & 1 & $\mathbf{5 v} ; 99(94)$ & 19.8 \\
\hline 23 & $\mathrm{R}=\mathrm{CH}_{2} \mathrm{OMe}(\mathbf{4 w})$ & 24 & $5 \mathbf{5} ; 98(73)$ & 0.8 \\
\hline 24 & $\mathrm{R}=\mathrm{CH}_{2}$-2-thienyl $(\mathbf{4 x})$ & 7 & $\mathbf{5 x} ; 98(86)$ & 2.8 \\
\hline $25^{d}$ & $\mathrm{R}=\mathrm{Ph}(\mathbf{4 a})$ & 24 & $\mathbf{5 a} ; 93$ & 0.8 \\
\hline $26^{d}$ & $\mathrm{R}=2-$ Pyridyl $(\mathbf{4 i})$ & 2 & 5i; 99 & 9.9 \\
\hline
\end{tabular}

${ }^{a}$ Reactions performed under a $\mathrm{N}_{2}$ atmosphere at $100{ }^{\circ} \mathrm{C}$ using $1 \mathrm{mmol}$ of the corresponding nitrile (0.33 M in water). Substrate/Rh ratio: $100 / 5 .{ }^{b}$ Yields determined by GC (uncorrected GC 
areas). Isolated yields after appropriate workup are given in brackets. ${ }^{c}$ Turnover frequencies ((mol product/mol Rh)/time). ${ }^{d}$ Reactions performed in the presence of $\mathrm{Hg}(0)$.

Extremely fast reactions were also observed with 2-pyrimidinecarbonitrile (4I) and pyrazinecarbonitrile (4m) (entries 12 and 13). In particular, hydration of $\mathbf{4 m}$ allowed the isolation of pure pyrazinamide $(\mathbf{5 m})$, a drug used to treat tuberculosis, ${ }^{39}$ in $82 \%$ yield. Also worthy of note is that, similarly to the case of cyanopyridines, a much higher reactivity was observed with 2-thiophenecarbonitrile (4n) and 5-methyl-2furanecarbonitrile (4p) in comparison with the related systems 3-thiophenecarbonitrile (4o) and 3-furanecarbonitrile (4q) (entries 14 vs 15 and 16 vs 17). Resonance effects can be again evoked to rationalize these observations. It must be stressed in this point that the higher reactivity of $\left[\mathrm{RhCl}(\mathrm{COD})\left\{\mathrm{P}\left(\mathrm{NMe}_{2}\right)_{3}\right\}\right]$ (3h) towards heteroaromatic vs simple aromatic substrates clearly differentiates this catalysts from the other rhodium-based systems previously described in the literature, where such differences were not noted. ${ }^{16-}$ 19 For example, using the $\left[\{\mathrm{Rh}(\mu-\mathrm{OMe})(\mathrm{COD})\}_{2}\right] / \mathrm{PCy}_{3}$ system, benzonitrile and 2thiophenecarbonitrile were hydrated with an identical TOF of $825 \mathrm{~h}^{-1}{ }^{18}$ Similar TOF values of around $90 \mathrm{~h}^{-1}$ were also reached in the hydration of benzonitrile and 2furanecarbonitrile with the rhodium(I)-NHC complex A (Figure 2). ${ }^{19}$ Indeed, in our knowledge, such behaviour has not precedents with any homogeneous catalyst. ${ }^{40}$ Only heterogeneous systems, such as $\mathrm{Au} / \mathrm{TiO}_{2}, \mathrm{CeO}_{2}$ or $\mathrm{Ni}_{0.7} \mathrm{Mn}_{0.3} \mathrm{O}$, have shown a comparatively higher effectiveness with heteroaromatic nitriles. ${ }^{41}$ The preferred anchoring of the substrates to the catalysts surface through the heterocyclic ring, instead of the nitrile function, was in these cases proposed to explain the differences in activity observed. This raised the possibility that rhodium nanoparticles could be the real catalytically active species in our hydration reactions, a fact that was ruled out performing the catalytic experiments in the presence of elemental mercury. ${ }^{42 a}$ No major differences in activity were observed when some drops of $\mathrm{Hg}(0)$ were added to the reaction media (see entries 25 and 26 in Table 3). ${ }^{42 b}$ The enhanced reactivity of $\left[\mathrm{RhCl}(\mathrm{COD})\left\{\mathrm{P}\left(\mathrm{NMe}_{2}\right)_{3}\right\}\right]$ (3h) towards heteroaromatic substrates must therefore be related to the electronic nature of these nitriles, the strong activating effect of the heterocycles being probably responsible of the differences in reactivity found. However, we can not totally discard that the participation of the heteroatom in an extended $\mathrm{H}$ bonded network with the water molecules can also be facilitating the nucleophilic addition of water to the $\mathrm{C} \equiv \mathrm{N}$ bond. 
The hydration of aliphatic nitriles was also examined with complex $\mathbf{3 h}$. Very poor conversions were obtained with heptanenitrile (4r) and acetonitrile (4s) after $24 \mathrm{~h}$ (entries 19 and 20 in Table 3). The low activity is probably due to the increased electron density of the nitrile carbon atom in these substrates, which make the nucleophilic attack of water less favourable than in the preceding cases. However, the introduction of heteroatoms in $\beta$-position with respect to the $\mathrm{C} \equiv \mathrm{N}$ unit resulted beneficial and the hydration processes proceeded in these cases to completion. Thus, chloroacetonitrile $(\mathbf{4 t})$, trichloroacetonitrile $(\mathbf{4 u})$, phenoxyacetonitrile $(\mathbf{4 v})$ and methoxyacetonitrile $(\mathbf{4 w})$ were converted to the corresponding primary amides $\mathbf{5 r}-\mathbf{s}$ in $\geq 95 \%$ GC-yield after 1-24 $\mathrm{h}$ of reaction (entries 20-23). ${ }^{43}$ This may be again understood in terms of the enhancement of the electrophilicity of the nitrile carbon atom by the substituents. The higher inductive effects of the chlorine atoms and the phenoxy group $v s$ the methoxy group are fully consistent with the reaction times observed. ${ }^{44}$ For trichloroacetonitrile (4u) a significant TOF value of $38.8 \mathrm{~h}^{-1}$ could be attained (entry 23). A good result was also obtained with 2-thienylacetonitrile (4x) (98\% conversion after $7 \mathrm{~h}$; entry 24$)$.

The subtle sensitivity of $\left[\mathrm{RhCl}(\mathrm{COD})\left\{\mathrm{P}\left(\mathrm{NMe}_{2}\right)_{3}\right\}\right]$ (3h) to the electronic characteristics of the nitrile substituents was clearly evidenced in the reaction of the dinitrile $\mathbf{4 y}$, which could be selectively transformed into the monoamide $\mathbf{5 y}$, in which the less activated nitrile group remains intact (Scheme 3).

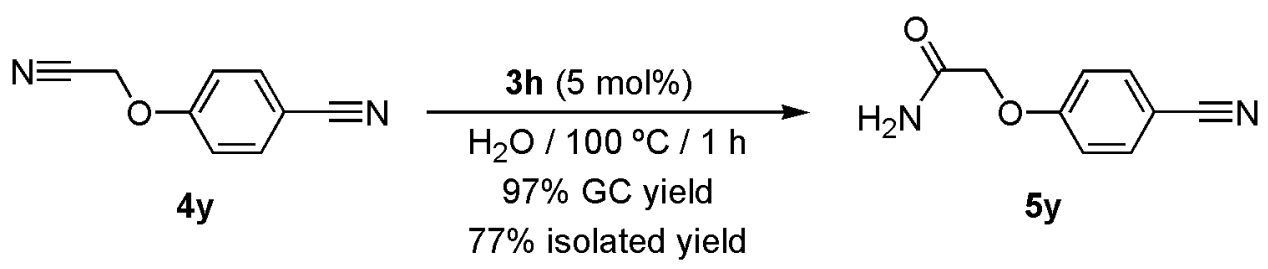

Scheme 3. Selective monohydration of the dinitrile $4 \mathbf{y}$ using $\left[\mathrm{RhCl}(\mathrm{COD})\left\{\mathrm{P}\left(\mathrm{NMe}_{2}\right)_{3}\right\}\right](\mathbf{3 h})$.

It should also be noted that, although the catalytic activity shown by complex $\left[\mathrm{RhCl}(\mathrm{COD})\left\{\mathrm{P}\left(\mathrm{NMe}_{2}\right)_{3}\right\}\right](\mathbf{3 h})$ is in general lower than those recently described for related ruthenium complexes with cooperative phosphine ligands, such as $\left[\mathrm{RuCl}_{2}\left(\eta^{6}\right.\right.$ $\left.\left.\mathrm{C}_{6} \mathrm{Me}_{6}\right)\left\{\mathrm{P}\left(\mathrm{NMe}_{2}\right)_{3}\right\}\right](\mathbf{6}),{ }^{10 \mathrm{~b}}\left[\mathrm{RuCl}_{2}\left(\eta^{6}-p\right.\right.$-cymene $\left.)(\mathrm{L})\right]\left(\mathrm{L}=\mathrm{PMe}_{2} \mathrm{OH}(7),{ }^{11 \mathrm{~b}} \operatorname{tris}(5-(2-\right.$ aminothiazolyl))phosphinetrihydrochloride $\left.(\mathbf{8})^{8}\right)$ and $\left[\mathrm{RuCl}_{2}\left(\eta^{3}: \eta^{3}-\mathrm{C}_{10} \mathrm{H}_{16}\right)(\mathrm{THPA})\right](\mathbf{9})^{9 \mathrm{~b}}$ (TOF values within the range 9.9-26.4 $\mathrm{h}^{-1}$ for the hydration of benzonitrile (4a) under identical reaction conditions to those indicated in Table 3), for the particular case of 
heteroaromatic nitriles its effectiveness is comparable or even higher. A proof of this is, for example, the greater activity found for $\left[\mathrm{RhCl}(\mathrm{COD})\left\{\mathrm{P}\left(\mathrm{NMe}_{2}\right)_{3}\right\}\right]$ (3h) in the catalytic hydration of 4-cyano-1-(2,6-difluorobenzyl)-1H-1,2,3-triazole (4z) into rufinamide (5z) (Scheme 4), a relevant amide used as drug in the treatment of the Lennox-Gastaut syndrome (a severe form of epilepsy) and other seizure disorders. ${ }^{45,46}$ Using complex $\left[\mathrm{RhCl}(\mathrm{COD})\left\{\mathrm{P}\left(\mathrm{NMe}_{2}\right)_{3}\right\}\right](\mathbf{3 h})$, and our standard reaction conditions, an almost quantitative formation of rufinamide (5z) was observed by $\mathrm{GC}$ after $3 \mathrm{~h}$ of heating ( $83 \%$ isolated yield after appropriate work-up). Among the various ruthenium catalysts tested in this work, only $\left[\mathrm{RuCl}_{2}\left(\eta^{6}-\mathrm{C}_{6} \mathrm{Me}_{6}\right)\left\{\mathrm{P}\left(\mathrm{NMe}_{2}\right)_{3}\right\}\right](6)$ showed a so high reactivity (Scheme 4). To the best of our knowledge this is the first time that metal catalysts are involved in the preparation of rufinamide.
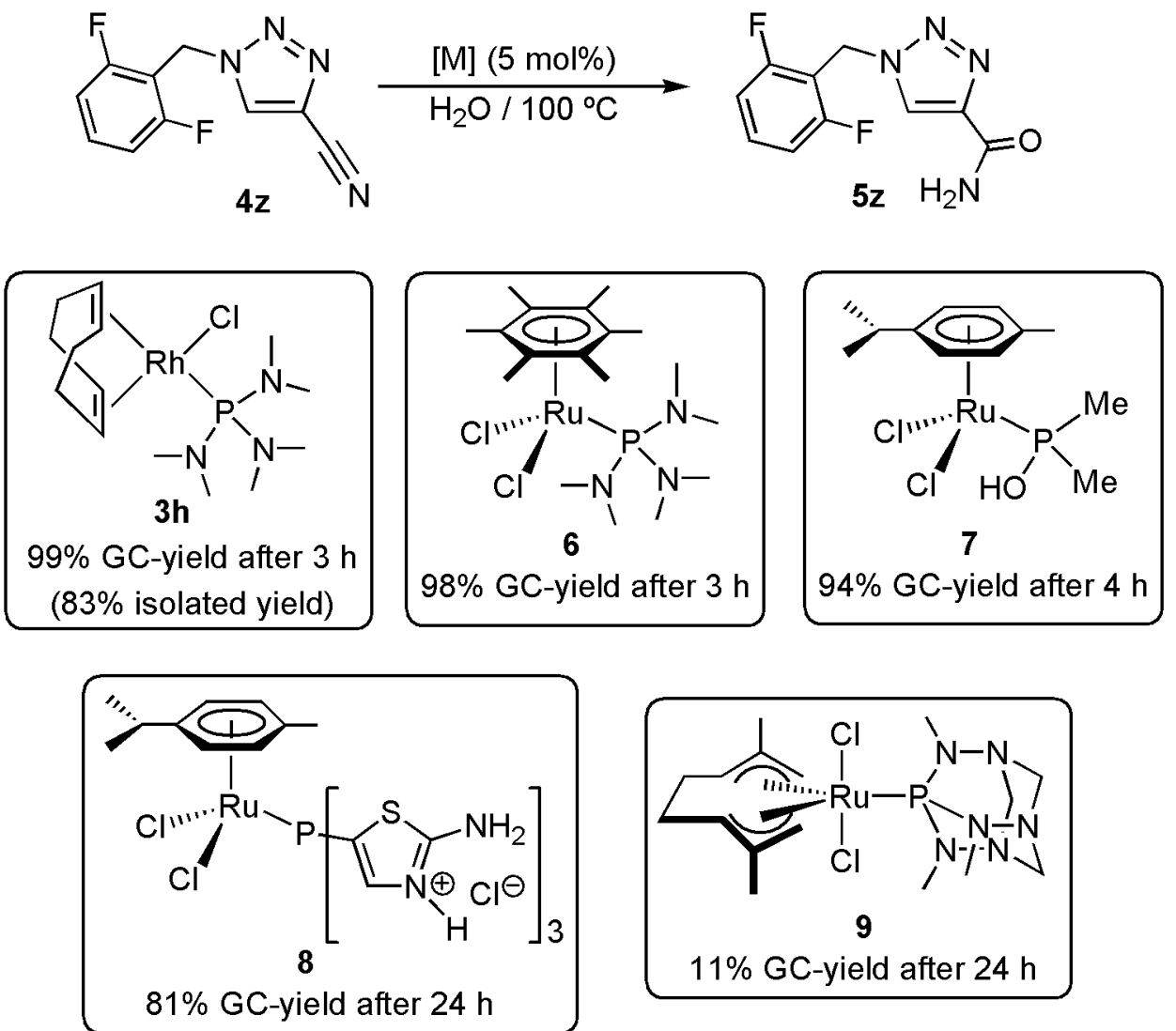

Scheme 4. Catalytic synthesis of rufinamide $(5 \mathbf{z})$ by hydration of nitrile $\mathbf{4 z}$.

\section{Conclusion}


In summary, different rhodium(I)-phosphine complexes $\left[\mathrm{RhCl}(\mathrm{COD})\left(\mathrm{PR}_{3}\right)\right]$ have been evaluated as potential catalysts for the selective hydration of organonitriles into amides in water. Among the different ligands screened, aminophosphines of general composition $\mathrm{P}\left(\mathrm{NR}_{2}\right)_{3}$ were found to be particularly useful to develop catalytic systems featuring a high activity. Indeed, one of the complexes synthesized with this type of ligands, namely $\left[\mathrm{RhCl}(\mathrm{COD})\left\{\mathrm{P}\left(\mathrm{NMe}_{2}\right)_{3}\right\}\right]$, was able to promote efficiently the selective hydration of a large range of organonitriles, representing the first rhodium-based catalyst able to operate in pure water without the assistance of any acidic or basic additive. In addition, complex $\left[\mathrm{RhCl}(\mathrm{COD})\left\{\mathrm{P}\left(\mathrm{NMe}_{2}\right)_{3}\right\}\right]$ has proved to be very sensitive to the electronic nature of the substrates, showing a particularly high reactivity with different series of heteroaromatic and heteroaliphatic nitriles. The synthetic utility of $\left[\mathrm{RhCl}(\mathrm{COD})\left\{\mathrm{P}\left(\mathrm{NMe}_{2}\right)_{3}\right\}\right]$ was also fully demonstrated in the high-yield preparation of the antiepileptic drug rufinamide by catalytic hydration of 4-cyano-1-(2,6difluorobenzyl)-1H-1,2,3-triazole, reaction in which complex $\left[\mathrm{RhCl}(\mathrm{COD})\left\{\mathrm{P}\left(\mathrm{NMe}_{2}\right)_{3}\right\}\right]$ proved to be more effective than a number of related ruthenium-based nitrile hydration catalysts.

\section{Experimental Section}

Synthetic procedures were performed under an atmosphere of dry nitrogen using vacuum-line and standard Schlenk techniques. Organic solvents were dried by standard methods and distilled under nitrogen before use. All reagents were obtained from commercial suppliers and used without further purification with the exception of the phosphine ligands $\mathrm{PPh}_{2}$ py (2b) ${ }^{47} \mathrm{PPh}_{2}($ py-4-NMe $)(\mathbf{2 c}),{ }^{48} \mathrm{PPh}_{2}$ (py-6-tert-amyl) (2d) ${ }^{49}$ PTA (2e),${ }^{50}$ DAPTA (2f) $,{ }^{51} \mathrm{PPh}_{2}\left(\mathrm{NMe}_{2}\right)(\mathbf{2 g}),{ }^{52} \mathrm{P}(N \text {-pyrrolidinyl })_{3}(\mathbf{2 j}),{ }^{53} \mathrm{P}(N \text {-pyrrolyl })_{3}$ (2k), ${ }^{53}$ THPA $(\mathbf{2 l})^{54}$ and THDP $(\mathbf{2 m}),{ }^{55}$ the $\mathrm{Rh}(\mathrm{I})$ complexes $\left[\{\mathrm{Rh}(\mu-\mathrm{Cl})(\mathrm{COD})\}_{2}\right](\mathbf{1}),{ }^{56}$ $\left[\mathrm{RhCl}(\mathrm{COD})\left(\mathrm{PPh}_{3}\right)\right](\mathbf{3 a}),{ }^{20}\left[\mathrm{RhCl}(\mathrm{COD})\left(\mathrm{PPh}_{2} \mathrm{py}\right)\right](\mathbf{3 b}),{ }^{21}[\mathrm{RhCl}(\mathrm{COD})(\mathrm{THPA})](\mathbf{3 l}),{ }^{22}$ $\left[\{\mathrm{RhCl}(\mathrm{COD})\}_{2}(\mu-\mathrm{THDP})\right] \quad(\mathbf{3 m})^{26}$ and $\left[\mathrm{RhCl}(\mathrm{COD})\left\{\mathrm{P}(\mathrm{OMe})_{3}\right\}\right] \quad(\mathbf{3 n}){ }^{20}$ and the organonitriles 4-cyanophenoxyacetonitrile $(4 \mathbf{y})^{57}$ and 4-cyano-1-(2,6-difluorobenzyl)$1 H$-1,2,3-triazole $(\mathbf{4 z}),{ }^{58}$ and the ruthenium complexes $\left[\mathrm{RuCl}_{2}\left(\eta^{6}-\mathrm{C}_{6} \mathrm{Me}_{6}\right)\left\{\mathrm{P}\left(\mathrm{NMe}_{2}\right)_{3}\right\}\right]$
$(6),{ }^{10 \mathrm{~b}}$
$\left[\mathrm{RuCl}_{2}\left(\eta^{6}-p\right.\right.$-cymene $\left.)(\mathrm{L})\right]$
$\left(\mathrm{L}=\mathrm{PMe}_{2} \mathrm{OH}\right.$
$(7),{ }^{11 \mathrm{~b}}$
$\operatorname{tris}(5-(2-$ aminothiazolyl))phosphinetrihydrochloride $\left.(\mathbf{8})^{8}\right)$ and $\left[\mathrm{RuCl}_{2}\left(\eta^{3}: \eta^{3}-\mathrm{C}_{10} \mathrm{H}_{16}\right)\right.$ (THPA)] (9), ${ }^{9 \mathrm{~b}}$ which were prepared by following the methods reported in the literature. Infrared 
spectra were recorded on a Perkin-Elmer 1720-XFT spectrometer. GC measurements were made on a Hewlett-Packard HP6890 equipment using a Supelco Beta-Dex ${ }^{\mathrm{TM}} 120$ column (30 m length; $250 \mu \mathrm{m}$ diameter). NMR spectra were recorded on a Bruker DPX300 or AV400 instruments. The chemical shift values $(\delta)$ are given in parts per million and are referred to the residual peak of the deuterated solvent employed $\left({ }^{1} \mathrm{H}\right.$ and $\left.{ }^{13} \mathrm{C}\right)$ or an external $85 \%$ aqueous $\mathrm{H}_{3} \mathrm{PO}_{4}$ solution $\left({ }^{31} \mathrm{P}\right)$. DEPT experiments have been carried out for all the compounds reported. Elemental analyses were provided by the Analytical Service of the Instituto de Investigaciones Químicas (IIQ-CSIC) of Seville.

\section{Synthesis of complexes $\left[\mathrm{RhCl}(\mathrm{COD})\left(\mathrm{PR}_{3}\right)\right]\left(\mathrm{PR}_{3}=\mathrm{PPh}_{2}\left(\mathrm{py}-4-\mathrm{NMe}_{2}\right)(3 \mathrm{c}), \mathrm{PPh}_{2}(\mathrm{py}-\right.$ 6-tert-amyl) (3d), PTA (3e), DAPTA (3f), PPh $2\left(\mathrm{NMe}_{2}\right)(3 g), \mathrm{P}\left(\mathrm{NMe}_{2}\right)_{3}(3 \mathrm{~h}), \mathrm{P}\left(\mathrm{NEt}_{2}\right)_{3}$} (3i), P(N-pyrrolidinyl $\left.)_{3}(3 \mathbf{j}), \mathbf{P}(N \text {-pyrrolyl })_{3}(3 \mathbf{k})\right)$. A solution of the $\mathrm{Rh}(\mathrm{I})$ dimer [\{ $\left.\mathrm{Rh}(\mu-\mathrm{Cl})(\mathrm{COD})\}_{2}\right](\mathbf{1})(0.197 \mathrm{~g}, 0.400 \mathrm{mmol})$ and the corresponding phosphine ligand $(0.820 \mathrm{mmol})$ in tetrahydrofuran $(20 \mathrm{~mL})$ was stirred at room temperature for $1.5 \mathrm{~h}$. The solvent was then removed under reduced pressure to give a yellow solid residue (oily residue in the case of $\mathbf{3 i}$ ), which was washed twice with $15 \mathrm{~mL}$ of a hexane/diethyl ether mixture $(1: 1 \mathrm{v} / \mathrm{v})$ and dried in vacuo. (3c): Yield: $0.353 \mathrm{~g}(80 \%)$. Anal. Calcd for $\mathrm{C}_{27} \mathrm{H}_{31} \mathrm{~N}_{2} \mathrm{ClPRh}$ : C, 58.65; H, 5.65; N, 5.07. Found: C, 58.79; H, 5.57; N, 5.20. IR (KBr): v $3051(\mathrm{w}), 2921(\mathrm{~m}), 2824(\mathrm{w}), 1589(\mathrm{~m}), 1536(\mathrm{w}), 1480(\mathrm{w}), 1435(\mathrm{~s}), 1376$ (m), 1266 (w), 1187 (m), 1027 (w), 985 (s), 829 (w), $746(\mathrm{w}), 698(\mathrm{~m}), 554(\mathrm{w}), 533$ (m) $\mathrm{cm}^{-1} .{ }^{31} \mathrm{P}\left\{{ }^{1} \mathrm{H}\right\}$ NMR $\left(\mathrm{CD}_{2} \mathrm{Cl}_{2}\right) \delta 30.9\left(\mathrm{~d},{ }^{1} J_{\mathrm{RhP}}=149.6 \mathrm{~Hz}\right) \mathrm{ppm} .{ }^{1} \mathrm{H}$ NMR $\left(\mathrm{CD}_{2} \mathrm{Cl}_{2}\right)$ $\delta 2.04\left(\mathrm{~m}, 4 \mathrm{H}, \mathrm{CH}_{2}\right), 2.42\left(\mathrm{~m}, 4 \mathrm{H}, \mathrm{CH}_{2}\right), 2.97$ (s, 6H, N( $\left.\left.\mathrm{CH}_{3}\right)_{2}\right), 4.44$ (br, 2H, =CH), $5.36(\mathrm{br}, 2 \mathrm{H},=\mathrm{CH}), 6.48\left(\mathrm{~m}, 1 \mathrm{H}, \mathrm{CH}_{\text {arom }}\right), 7.43\left(\mathrm{~m}, 7 \mathrm{H}, \mathrm{CH}_{\text {arom }}\right), 7.84\left(\mathrm{~m}, 4 \mathrm{H}, \mathrm{CH}_{\text {arom }}\right)$, $8.27\left(\mathrm{~d}, 1 \mathrm{H},{ }^{3} \mathrm{~J}_{\mathrm{HH}}=5.7 \mathrm{~Hz}, \mathrm{CH}_{\text {arom }}\right) \mathrm{ppm} .{ }^{13} \mathrm{C}\left\{{ }^{1} \mathrm{H}\right\} \mathrm{NMR}\left(\mathrm{CD}_{2} \mathrm{Cl}_{2}\right) \delta 28.3\left(\mathrm{br}, \mathrm{CH}_{2}\right), 31.0$ (br, $\left.\mathrm{CH}_{2}\right), 38.8\left(\mathrm{~s}, \mathrm{~N}\left(\mathrm{CH}_{3}\right)_{2}\right), 68.0\left(\mathrm{~d},{ }^{1} J_{\mathrm{RhC}}=13.9 \mathrm{~Hz},=\mathrm{CH}\right), 106.1\left(\mathrm{~s}, \mathrm{CH}_{\text {arom }}\right), 107.4$ (br, $=\mathrm{CH}), 116.5\left(\mathrm{~d},{ }^{2} J_{\mathrm{PC}}=32.2 \mathrm{~Hz}, \mathrm{CH}_{\text {arom }}\right), 127.7\left(\mathrm{~d},{ }^{2} J_{\mathrm{PC}}=10.1 \mathrm{~Hz}, \mathrm{CH}_{\text {arom }}\right), 129.9$ (s, $\left.\mathrm{CH}_{\text {arom }}\right), 132.0\left(\mathrm{~d},{ }^{1} J_{\mathrm{PC}}=51.3 \mathrm{~Hz}, \mathrm{C}_{\text {arom }}\right), 135.1\left(\mathrm{~d},{ }^{3} J_{\mathrm{PC}}=11.1 \mathrm{~Hz}, \mathrm{CH}_{\text {arom }}\right), 149.5(\mathrm{~d}$, $\left.{ }^{3} J_{\mathrm{PC}}=15.1 \mathrm{~Hz}, \mathrm{CH}_{\text {arom }}\right), 153.5\left(\mathrm{~d},{ }^{3} J_{\mathrm{PC}}=15.1 \mathrm{~Hz}, \mathrm{C}_{\mathrm{arom}}\right), 156.2\left(\mathrm{~d},{ }^{1} J_{\mathrm{PC}}=61.4 \mathrm{~Hz}\right.$, Carom $)$ ppm. (3d): Yield: 0.394 g (85\%). Anal. Calcd for $\mathrm{C}_{30} \mathrm{H}_{36} \mathrm{ClNPRh}$ C, 62.13; H, 6.26; N, 2.42. Found: C, 61.92; H, 6.40; N, 2.61. IR (KBr): v 3053 (w), 2961 (m), 2878 (m), 2830 (w), 1575 (m), 1557 (s), 1480 (m), 1434 (s), 1387 (m), 1333 (w), 1310 (w), 1185 (w), 1169 (w), 1093 (s), 1028 (w), 992 (m), 960 (w), 858 (w), 807 (m), 742 (s), 700 (s) $\mathrm{cm}^{-1} .{ }^{31} \mathrm{P}\left\{{ }^{1} \mathrm{H}\right\}$ NMR $\left(\mathrm{CDCl}_{3}\right) \delta 29.4\left(\mathrm{~d},{ }^{1} J_{\mathrm{RhP}}=151.8 \mathrm{~Hz}\right) \mathrm{ppm} .{ }^{1} \mathrm{H}$ NMR $\left(\mathrm{CDCl}_{3}\right) \delta 0.62$ $\left(\mathrm{t}, 3 \mathrm{H},{ }^{3} J_{\mathrm{HH}}=6.0 \mathrm{~Hz}, \mathrm{CH}_{2} \mathrm{CH}_{3}\right), 1.27\left(\mathrm{~s}, 6 \mathrm{H}, \mathrm{C}\left(\mathrm{CH}_{3}\right)_{2}\right), 1.71\left(\mathrm{q}, 2 \mathrm{H},{ }^{3} J_{\mathrm{HH}}=6.0 \mathrm{~Hz}\right.$, 
$\left.\mathrm{CH}_{2} \mathrm{CH}_{3}\right), 2.00\left(\mathrm{~m}, 4 \mathrm{H}, \mathrm{CH}_{2}\right), 2.42\left(\mathrm{~m}, 4 \mathrm{H}, \mathrm{CH}_{2}\right), 3.39$ (br, 2H, =CH), 5.59 (br, $2 \mathrm{H}$, $=\mathrm{CH}), 7.24-7.78\left(\mathrm{~m}, 13 \mathrm{H}, \mathrm{CH}_{\text {arom }}\right) \mathrm{ppm} .{ }^{13} \mathrm{C}\left\{{ }^{1} \mathrm{H}\right\} \mathrm{NMR}\left(\mathrm{CDCl}_{3}\right) \delta 9.1\left(\mathrm{~s}, \mathrm{CH}_{2} \mathrm{CH}_{3}\right)$, $27.3\left(\mathrm{~s}, \mathrm{C}\left(\mathrm{CH}_{3}\right)_{2}\right), 28.9\left(\mathrm{~s}, \mathrm{CH}_{2}\right), 33.0\left(\mathrm{~s}, \mathrm{CH}_{2}\right), 35.7\left(\mathrm{~s}, \mathrm{CH}_{2} \mathrm{CH}_{3}\right), 41.2\left(\mathrm{~s}, C\left(\mathrm{CH}_{3}\right)_{2}\right)$, $70.5\left(\mathrm{~d},{ }^{1} J_{\mathrm{RhC}}=13.6 \mathrm{~Hz},=\mathrm{CH}\right), 104.9\left(\mathrm{dd},{ }^{1} J_{\mathrm{RhC}}=12.1 \mathrm{~Hz},{ }^{2} J_{\mathrm{PC}}=7.5 \mathrm{~Hz},=\mathrm{CH}\right), 120.1$ (s, $\left.\mathrm{CH}_{\text {arom }}\right), 127.7\left(\mathrm{~d},{ }^{2} J_{\mathrm{PC}}=9.5 \mathrm{~Hz}, \mathrm{CH}_{\text {arom }}\right), 128.7\left(\mathrm{~d},{ }^{3} J_{\mathrm{PC}}=26.5 \mathrm{~Hz}, \mathrm{CH}_{\text {arom }}\right), 130.0(\mathrm{~s}$, $\mathrm{CH}_{\text {arom }}$ ), $132.0\left(\mathrm{~d},{ }^{1} J_{\mathrm{PC}}=43.0 \mathrm{~Hz}, \mathrm{C}_{\text {arom }}\right), 132.1\left(\mathrm{~d},{ }^{2} J_{\mathrm{PC}}=9.7 \mathrm{~Hz}, \mathrm{CH}_{\text {arom }}\right), 135.4\left(\mathrm{~d},{ }^{3} J_{\mathrm{PC}}\right.$ $\left.=11.8 \mathrm{~Hz}, \mathrm{CH}_{\mathrm{arom}}\right), 155.7\left(\mathrm{~d},{ }^{1} J_{\mathrm{PC}}=62.6 \mathrm{~Hz}, \mathrm{C}_{\mathrm{arom}}\right), 167.9\left(\mathrm{~d},{ }^{3} J_{\mathrm{PC}}=12.1 \mathrm{~Hz}, \mathrm{C}_{\mathrm{arom}}\right)$ ppm. (3e): Yield: $0.290 \mathrm{~g}(90 \%)$. Anal. Calcd for $\mathrm{C}_{14} \mathrm{H}_{24} \mathrm{~N}_{3} \mathrm{ClPRh}$ : C, 41.65; H, 5.99; N, 10.41. Found: C, 41.78; H, 5.90; N, 10.65. IR (KBr): v 2995 (w), 2938 (m), $2874(\mathrm{w})$, 1470 (w), 1418 (m), 1334 (w), 1290 (m), 1278 (s), 1241 (s), 1157 (m), 1055 (m), 1015 (m), 971 (s), 947 (s), 898 (m), $867(\mathrm{w}), 801$ (m), 743 (m), 502 (s), $481(\mathrm{~m}) \mathrm{cm}^{-1}$. ${ }^{31} \mathrm{P}\left\{{ }^{1} \mathrm{H}\right\}$ NMR $\left(\mathrm{CDCl}_{3}\right) \delta-52.9\left(\mathrm{~d},{ }^{1} J_{\mathrm{RhP}}=149.4 \mathrm{~Hz}\right) \mathrm{ppm} .{ }^{1} \mathrm{H} \mathrm{NMR}\left(\mathrm{CDCl}_{3}\right) \delta 2.06(\mathrm{~m}$, $\left.4 \mathrm{H}, \mathrm{CH}_{2}\right), 2.35\left(\mathrm{~m}, 4 \mathrm{H}, \mathrm{CH}_{2}\right), 3.59$ (br, $\left.2 \mathrm{H},=\mathrm{CH}\right), 4.17\left(\mathrm{~s}, 6 \mathrm{H}, \mathrm{PCH}_{2} \mathrm{~N}\right.$ or $\left.\mathrm{NCH}_{2} \mathrm{~N}\right), 4.49$ $\left(\mathrm{m}, 6 \mathrm{H}, \mathrm{PCH}_{2} \mathrm{~N}\right.$ or $\left.\mathrm{NCH}_{2} \mathrm{~N}\right), 5.40(\mathrm{br}, 2 \mathrm{H},=\mathrm{CH}) \operatorname{ppm} .{ }^{13} \mathrm{C}\left\{{ }^{1} \mathrm{H}\right\} \mathrm{NMR}\left(\mathrm{CDCl}_{3}\right) \delta 28.2(\mathrm{~s}$, $\left.\mathrm{CH}_{2}\right), 33.4\left(\mathrm{~s}, \mathrm{CH}_{2}\right), 50.4\left(\mathrm{~d},{ }^{1} J_{\mathrm{PC}}=11.1 \mathrm{~Hz}, \mathrm{PCH}_{2} \mathrm{~N}\right), 67.4\left(\mathrm{~d},{ }^{1} J_{\mathrm{RhC}}=14.1 \mathrm{~Hz},=\mathrm{CH}\right)$, $73.2\left(\mathrm{~d},{ }^{2} \mathrm{~J}_{\mathrm{PC}}=7.0 \mathrm{~Hz}, \mathrm{NCH}_{2} \mathrm{~N}\right), 107.3(\mathrm{br},=\mathrm{CH})$ ppm. (3f): Yield: $0.315 \mathrm{~g}(83 \%)$. Anal. Calcd for $\mathrm{C}_{17} \mathrm{H}_{28} \mathrm{~N}_{3} \mathrm{O}_{2}$ ClPRh: C, 42.92; H, 5.93; N, 8.83. Found: C, 43.09; H, 6.10; N, 8.61. IR (KBr): v 3004 (w), 2938 (w), 2879 (m), 2830 (w), 1636 (vs), 1465 (m), 1409 (s), 1350 (m), 1302 (w), 1236 (m), 1207 (m), 1121 (w), 1100 (m), 1048 (s), 995 (s), 958 (w), 892 (s), 871 (w), $797(\mathrm{~m}), 705$ (w), 629 (w), 565 (m), $497(\mathrm{w}), 469(\mathrm{w}) \mathrm{cm}^{-1}$. ${ }^{31} \mathrm{P}\left\{{ }^{1} \mathrm{H}\right\} \mathrm{NMR}\left(\mathrm{CDCl}_{3}\right) \delta-29.2\left(\mathrm{~d},{ }^{1} J_{\mathrm{RhP}}=153.1 \mathrm{~Hz}\right) \mathrm{ppm} .{ }^{1} \mathrm{H} \mathrm{NMR}\left(\mathrm{CDCl}_{3}\right) \delta 2.08(\mathrm{~s}$, $\left.3 \mathrm{H}, \mathrm{CH}_{3}\right), 2.10\left(\mathrm{~s}, 3 \mathrm{H}, \mathrm{CH}_{3}\right), 2.11\left(\mathrm{~m}, 4 \mathrm{H}, \mathrm{CH}_{2}\right), 2.45\left(\mathrm{~m}, 4 \mathrm{H}, \mathrm{CH}_{2}\right), 3.35\left(\mathrm{~d}, 1 \mathrm{H},{ }^{2} J_{\mathrm{HH}}=\right.$ $\left.19.5 \mathrm{~Hz}, \mathrm{PCH}_{2} \mathrm{~N}\right), 3.75(\mathrm{br}, 2 \mathrm{H},=\mathrm{CH}), 3.78-4.55\left(\mathrm{~m}, 6 \mathrm{H}, \mathrm{PCH}_{2} \mathrm{~N}\right.$ and $\left.\mathrm{NCH}_{2} \mathrm{~N}\right), 4.92(\mathrm{~d}$, $\left.1 \mathrm{H},{ }^{2} J_{\mathrm{HH}}=15.8 \mathrm{~Hz}, \mathrm{NCH}_{2} \mathrm{~N}\right), 5.36\left(\mathrm{~d}, 1 \mathrm{H},{ }^{2} J_{\mathrm{HH}}=19.5 \mathrm{~Hz}, \mathrm{NCH}_{2} \mathrm{~N}\right), 5.50(\mathrm{br}, 2 \mathrm{H}$, $=\mathrm{CH}), 5.76\left(\mathrm{~d}, 1 \mathrm{H},{ }^{2} J_{\mathrm{HH}}=15.8 \mathrm{~Hz}, \mathrm{NCH}_{2} \mathrm{~N}\right) \mathrm{ppm} .{ }^{13} \mathrm{C}\left\{{ }^{1} \mathrm{H}\right\} \mathrm{NMR}\left(\mathrm{CDCl}_{3}\right) \delta 21.3(\mathrm{~s}$, $\left.\mathrm{CH}_{3}\right), 21.6\left(\mathrm{~s}, \mathrm{CH}_{3}\right), 28.2\left(\mathrm{~d},{ }^{2} J_{\mathrm{RhC}}=6.1 \mathrm{~Hz}, \mathrm{CH}_{2}\right), 33.4\left(\mathrm{~d},{ }^{2} J_{\mathrm{RhC}}=9.6 \mathrm{~Hz}, \mathrm{CH}_{2}\right), 36.6$ $\left(\mathrm{d},{ }^{1} J_{\mathrm{PC}}=17.2 \mathrm{~Hz}, \mathrm{PCH}_{2} \mathrm{~N}\right), 42.4\left(\mathrm{~d},{ }^{1} J_{\mathrm{PC}}=15.2 \mathrm{~Hz}, \mathrm{PCH}_{2} \mathrm{~N}\right), 47.2\left(\mathrm{~d},{ }^{1} J_{\mathrm{PC}}=20.9 \mathrm{~Hz}\right.$, $\left.\mathrm{PCH}_{2} \mathrm{~N}\right), 62.0\left(\mathrm{~d},{ }^{2} J_{\mathrm{PC}}=3.8 \mathrm{~Hz}, \mathrm{NCH}_{2} \mathrm{~N}\right), 67.3\left(\mathrm{~d},{ }^{2} J_{\mathrm{PC}}=4.5 \mathrm{~Hz}, \mathrm{NCH}_{2} \mathrm{~N}\right), 68.4(\mathrm{dd}$, $\left.{ }^{1} J_{\mathrm{RhC}}=11.3 \mathrm{~Hz},{ }^{2} J_{\mathrm{PC}}=6.0 \mathrm{~Hz},=\mathrm{CH}\right), 108.5(\mathrm{br},=\mathrm{CH}), 169.5(\mathrm{~s}, \mathrm{C}=\mathrm{O}), 170.0(\mathrm{~s}, \mathrm{C}=\mathrm{O})$ ppm. (3g): Yield: 0.305 g (87\%). Anal. Calcd for $\mathrm{C}_{22} \mathrm{H}_{28} \mathrm{ClNPRh}: \mathrm{C}, 55.54 ; \mathrm{H}, 5.93$; N, 2.94. Found: C, 55.42; H, 6.19; N, 2.89. IR (KBr): v 3060 (w), 2994 (w), 2942 (m), 2867 (m), 2839 (m), 2796 (m), 1480 (w), 1432 (s), 1334 (w), 1279 (m), 1195 (s), 1097 (vs), 1070 (m), 985 (vs), 862 (m), 816 (w), 747 (w), 697 (vs), 671 (s), 545 (s), 502 (s), $466(\mathrm{~m}) \mathrm{cm}^{-1} \cdot{ }^{31} \mathrm{P}\left\{{ }^{1} \mathrm{H}\right\}$ NMR $\left(\mathrm{CDCl}_{3}\right) \delta 79.0\left(\mathrm{~d},{ }^{1} J_{\mathrm{RhP}}=159.7 \mathrm{~Hz}\right) \mathrm{ppm} .{ }^{1} \mathrm{H} \mathrm{NMR}$ 
$\left(\mathrm{CDCl}_{3}\right) \delta 1.98\left(\mathrm{~m}, 4 \mathrm{H}, \mathrm{CH}_{2}\right), 2.37\left(\mathrm{~m}, 4 \mathrm{H}, \mathrm{CH}_{2}\right), 3.05(\mathrm{br}, 2 \mathrm{H},=\mathrm{CH}), 3.06\left(\mathrm{~d}, 6 \mathrm{H},{ }^{3} J_{\mathrm{PH}}\right.$ $=9.3 \mathrm{~Hz}, \mathrm{NMe}), 5.53(\mathrm{br}, 2 \mathrm{H},=\mathrm{CH}), 7.43\left(\mathrm{~m}, 6 \mathrm{H}, \mathrm{CH}_{\text {arom }}\right), 7.65\left(\mathrm{~m}, 4 \mathrm{H}, \mathrm{CH}_{\text {arom }}\right)$ ppm. ${ }^{13} \mathrm{C}\left\{{ }^{1} \mathrm{H}\right\} \operatorname{NMR}\left(\mathrm{CDCl}_{3}\right) \delta 28.7\left(\mathrm{~s}, \mathrm{CH}_{2}\right), 33.1\left(\mathrm{~s}, \mathrm{CH}_{2}\right), 43.3\left(\mathrm{~d},{ }^{2} J_{\mathrm{PC}}=6.2 \mathrm{~Hz}, \mathrm{NMe}\right)$, $70.0\left(\mathrm{~d},{ }^{1} J_{\mathrm{RhC}}=14.0 \mathrm{~Hz},=\mathrm{CH}\right), 105.9\left(\mathrm{dd},{ }^{1} J_{\mathrm{RhC}}=12.8 \mathrm{~Hz},{ }^{2} J_{\mathrm{PC}}=6.7 \mathrm{~Hz},=\mathrm{CH}\right), 127.9$ $\left(\mathrm{d},{ }^{2} J_{\mathrm{PC}}=9.6 \mathrm{~Hz}, \mathrm{CH}_{\text {arom }}\right), 129.9\left(\mathrm{~s}, \mathrm{CH}_{\text {arom }}\right), 132.8\left(\mathrm{~d},{ }^{3} J_{\mathrm{PC}}=11.5 \mathrm{~Hz}, \mathrm{CH}_{\text {arom }}\right), 133.3(\mathrm{~d}$, $\left.{ }^{1} J_{\mathrm{PC}}=44.2 \mathrm{~Hz}, \mathrm{C}_{\text {arom}}\right)$ ppm. (3h): ${ }^{23}$ Yield: $0.285 \mathrm{~g}$ (87\%). Anal. Calcd for $\mathrm{C}_{14} \mathrm{H}_{30} \mathrm{~N}_{3} \mathrm{ClPRh}: \mathrm{C}, 41.04 ; \mathrm{H}, 7.38 ; \mathrm{N}, 10.26$. Found: $\mathrm{C}, 41.19 ; \mathrm{H}, 7.25 ; \mathrm{N}, 10.41$. IR (KBr): v $2996(\mathrm{w}), 2879(\mathrm{~m}), 2791(\mathrm{w}), 1480(\mathrm{w}), 1457$ (m), $1425(\mathrm{w}), 1279(\mathrm{~m}), 1196$ (s), 1066 (m), 986 (s), 961 (s), 757 (w), 710 (m), 660 (s), 514 (m), 486 (m) cm cm $^{-1}$. ${ }^{31} \mathrm{P}\left\{{ }^{1} \mathrm{H}\right\} \mathrm{NMR}\left(\mathrm{CDCl}_{3}\right) \delta 109.3\left(\mathrm{~d},{ }^{1} J_{\mathrm{RhP}}=194.4 \mathrm{~Hz}\right) \mathrm{ppm} .{ }^{1} \mathrm{H} \mathrm{NMR}\left(\mathrm{CDCl}_{3}\right) \delta 1.97(\mathrm{~m}$, $\left.4 \mathrm{H}, \mathrm{CH}_{2}\right), 2.34\left(\mathrm{~m}, 4 \mathrm{H}, \mathrm{CH}_{2}\right), 2.77\left(\mathrm{~d}, 18 \mathrm{H},{ }^{3} J_{\mathrm{PH}}=8.1 \mathrm{~Hz}, \mathrm{NMe}\right), 3.81$ (br, $\left.2 \mathrm{H},=\mathrm{CH}\right)$, $5.37(\mathrm{br}, 2 \mathrm{H},=\mathrm{CH}) \mathrm{ppm} .{ }^{13} \mathrm{C}\left\{{ }^{1} \mathrm{H}\right\} \mathrm{NMR}\left(\mathrm{CDCl}_{3}\right) \delta 28.3\left(\mathrm{~d},{ }^{2} J_{\mathrm{RhC}}=1.7 \mathrm{~Hz}, \mathrm{CH}_{2}\right), 33.5$ $\left(\mathrm{d},{ }^{2} J_{\mathrm{RhC}}=3.2 \mathrm{~Hz}, \mathrm{CH}_{2}\right), 39.5\left(\mathrm{~d},{ }^{2} J_{\mathrm{PC}}=8.1 \mathrm{~Hz}, \mathrm{NMe}\right), 65.2\left(\mathrm{~d},{ }^{1} J_{\mathrm{RhC}}=13.9 \mathrm{~Hz},=\mathrm{CH}\right)$, $106.0\left(\mathrm{dd},{ }^{1} J_{\mathrm{RhC}}=15.1 \mathrm{~Hz},{ }^{2} J_{\mathrm{PC}}=6.0 \mathrm{~Hz},=\mathrm{CH}\right)$ ppm. (3i): Yield: $0.332 \mathrm{~g}(84 \%)$. Anal. Calcd for $\mathrm{C}_{20} \mathrm{H}_{42} \mathrm{~N}_{3} \mathrm{ClPRh}$ : C, 48.64; H, 8.57; N, 8.51. Found: C, 48.91; H, 8.70; N, 8.69. IR (KBr): v 3197 (w), 2966 (s), 2931 (s), 2868 (s), 2830 (m), 1456 (m), 1378 (s), 1334 (m), 1294 (w), 1181 (s), 1101 (m), 1076 (w), 1053 (w), 1013 (s), 931 (s), 869 (w), $855(\mathrm{w}), 797(\mathrm{~m}), 650(\mathrm{~m}) \mathrm{cm}^{-1} .{ }^{31} \mathrm{P}\left\{{ }^{1} \mathrm{H}\right\} \mathrm{NMR}\left(\mathrm{C}_{6} \mathrm{D}_{6}\right) \delta 113.0\left(\mathrm{~d},{ }^{1} J_{\mathrm{RhP}}=196.3 \mathrm{~Hz}\right)$ ppm. ${ }^{1} \mathrm{H}$ NMR $\left(\mathrm{C}_{6} \mathrm{D}_{6}\right) \delta 1.16\left(\mathrm{t}, 18 \mathrm{H},{ }^{3} J_{\mathrm{HH}}=7.1 \mathrm{~Hz}, \mathrm{CH}_{3}\right), 1.89\left(\mathrm{~m}, 4 \mathrm{H}, \mathrm{CH}_{2}\right), 2.31(\mathrm{~m}$, $\left.4 \mathrm{H}, \mathrm{CH}_{2}\right), 3.30\left(\mathrm{dq}, 12 \mathrm{H},{ }^{3} J_{\mathrm{PH}}=14.2 \mathrm{~Hz},{ }^{3} J_{\mathrm{HH}}=7.1 \mathrm{~Hz}, \mathrm{NCH}_{2}\right), 3.83(\mathrm{br}, 2 \mathrm{H},=\mathrm{CH})$, $5.85(\mathrm{br}, 2 \mathrm{H},=\mathrm{CH}) \mathrm{ppm} .{ }^{13} \mathrm{C}\left\{{ }^{1} \mathrm{H}\right\} \mathrm{NMR}\left(\mathrm{C}_{6} \mathrm{D}_{6}\right) \delta 14.7\left(\mathrm{~s}, \mathrm{CH}_{3}\right), 28.5\left(\mathrm{~s}, \mathrm{CH}_{2}\right), 33.6(\mathrm{~s}$, $\left.\mathrm{CH}_{2}\right), 41.8\left(\mathrm{~d},{ }^{2} J_{\mathrm{PC}}=8.8 \mathrm{~Hz}, \mathrm{NCH}_{2}\right), 65.5\left(\mathrm{~d},{ }^{1} J_{\mathrm{RhC}}=14.1 \mathrm{~Hz},=\mathrm{CH}\right), 104.4\left(\mathrm{dd},{ }^{1} J_{\mathrm{RhC}}=\right.$ $\left.16.0 \mathrm{~Hz},{ }^{2} J_{\mathrm{PC}}=6.2 \mathrm{~Hz},=\mathrm{CH}\right) \mathrm{ppm}$. (3j): Yield: $0.363 \mathrm{~g}(93 \%)$. Anal. Calcd for $\mathrm{C}_{20} \mathrm{H}_{36} \mathrm{~N}_{3} \mathrm{ClPRh}: \mathrm{C}, 49.24 ; \mathrm{H}, 7.44 ; \mathrm{N}, 8.61$. Found: C, 49.48; H, 7.44; N, 8.33. IR (KBr): v 3185 (w), 2931 (s), 2859 (s), 2826 (s), 1457 (w), 1340 (w), 1194 (m), 1124 (s), 1067 (vs), 1001 (vs), 954 (m), 910 (w), 868 (w), 813 (w), 756 (m), 668 (w), 562 (s), 537 $(\mathrm{m}), 520(\mathrm{~s}) \mathrm{cm}^{-1} .{ }^{31} \mathrm{P}\left\{{ }^{1} \mathrm{H}\right\} \mathrm{NMR}\left(\mathrm{C}_{6} \mathrm{D}_{6}\right) \delta 90.3\left(\mathrm{~d},{ }^{1} J_{\mathrm{RhP}}=192.5 \mathrm{~Hz}\right) \mathrm{ppm} .{ }^{1} \mathrm{H}$ NMR $\left(\mathrm{C}_{6} \mathrm{D}_{6}\right) \delta 1.68\left(\mathrm{~m}, 12 \mathrm{H}, \mathrm{NCH}_{2} \mathrm{CH}_{2}\right), 1.90\left(\mathrm{~m}, 4 \mathrm{H}, \mathrm{CH}_{2}\right), 2.31\left(\mathrm{~m}, 4 \mathrm{H}, \mathrm{CH}_{2}\right), 3.37(\mathrm{~m}$, $\left.12 \mathrm{H}, \mathrm{NCH}_{2} \mathrm{CH}_{2}\right), 3.96(\mathrm{br}, 2 \mathrm{H},=\mathrm{CH}), 5.88(\mathrm{br}, 2 \mathrm{H},=\mathrm{CH}) \mathrm{ppm} .{ }^{13} \mathrm{C}\left\{{ }^{1} \mathrm{H}\right\} \mathrm{NMR}\left(\mathrm{C}_{6} \mathrm{D}_{6}\right) \delta$ $26.3\left(\mathrm{~d},{ }^{3} J_{\mathrm{PC}}=6.0 \mathrm{~Hz}, \mathrm{NCH}_{2} \mathrm{CH}_{2}\right), 28.4\left(\mathrm{~s}, \mathrm{CH}_{2}\right), 33.8\left(\mathrm{~s}, \mathrm{CH}_{2}\right), 48.5\left(\mathrm{~d},{ }^{2} \mathrm{~J}_{\mathrm{PC}}=6.3 \mathrm{~Hz}\right.$, $\left.\mathrm{NCH}_{2} \mathrm{CH}_{2}\right), 64.6\left(\mathrm{~d},{ }^{1} J_{\mathrm{RhC}}=14.2 \mathrm{~Hz},=\mathrm{CH}\right), 106.1\left(\mathrm{dd},{ }^{1} J_{\mathrm{RhC}}=15.9 \mathrm{~Hz},{ }^{2} J_{\mathrm{PC}}=5.9 \mathrm{~Hz}\right.$, $=\mathrm{CH})$ ppm. (3k): Yield: $0.357 \mathrm{~g}(94 \%)$. Anal. Calcd for $\mathrm{C}_{20} \mathrm{H}_{24} \mathrm{~N}_{3} \mathrm{ClPRh}: \mathrm{C}, 50.49 ; \mathrm{H}$, 5.08; N, 8.83. Found: C, 50.30; H, 5.33; N, 8.84. IR (KBr): v 3129 (w), 3089 (w), 3028 (w), 2946 (w), 2867 (w), 2824 (w), 1454 (s), 1426 (w), 1336 (w), 1288 (m), 1238 (m), 
1101 (vs), 1087 (s), 1063 (vs), 1051 (vs), 1040 (vs), 977 (m), 932 (w), 867 (m), 815 (w), $784(\mathrm{w}), 756$ (s), 734 (vs), 716 (m), 632 (m), 615 (s), 574 (m), 540 (s), 523 (s), 478 (w) $\mathrm{cm}^{-1} .{ }^{31} \mathrm{P}\left\{{ }^{1} \mathrm{H}\right\} \mathrm{NMR}\left(\mathrm{CDCl}_{3}\right) \delta 90.3\left(\mathrm{~d},{ }^{1} J_{\mathrm{RhP}}=231.9 \mathrm{~Hz}\right) \mathrm{ppm} .{ }^{1} \mathrm{H} \mathrm{NMR}\left(\mathrm{CDCl}_{3}\right) \delta$ $2.20\left(\mathrm{~m}, 4 \mathrm{H}, \mathrm{CH}_{2}\right), 2.45\left(\mathrm{~m}, 4 \mathrm{H}, \mathrm{CH}_{2}\right), 3.36(\mathrm{br}, 2 \mathrm{H},=\mathrm{CH}), 5.99$ (br, $\left.2 \mathrm{H},=\mathrm{CH}\right), 6.37$ $(\mathrm{m}, 6 \mathrm{H}, \mathrm{NCHCH}), 7.10(\mathrm{~m}, 6 \mathrm{H}, \mathrm{NCHCH}) \mathrm{ppm} .{ }^{13} \mathrm{C}\left\{{ }^{1} \mathrm{H}\right\} \mathrm{NMR}\left(\mathrm{CDCl}_{3}\right) \delta 28.5\left(\mathrm{~s}, \mathrm{CH}_{2}\right)$, $33.1\left(\mathrm{~s}, \mathrm{CH}_{2}\right), 73.8\left(\mathrm{~d},{ }^{1} J_{\mathrm{RhC}}=13.0 \mathrm{~Hz},=\mathrm{CH}\right), 113.0\left(\mathrm{~d},{ }^{3} J_{\mathrm{PC}}=7.4 \mathrm{~Hz}, \mathrm{NCHCH}\right), 114.9$ $\left(\mathrm{dd},{ }^{1} J_{\mathrm{RhC}}=15.1 \mathrm{~Hz},{ }^{2} J_{\mathrm{PC}}=5.6 \mathrm{~Hz},=\mathrm{CH}\right), 124.8\left(\mathrm{~d},{ }^{2} J_{\mathrm{PC}}=8.5 \mathrm{~Hz}, \mathrm{NCHCH}\right) \mathrm{ppm}$.

\section{General procedure for the catalytic hydration of nitriles employing complex} $\left.\left[\mathbf{R h C l}(\mathbf{C O D})\left\{\mathbf{P}\left(\mathbf{N M e}_{2}\right)_{3}\right\}\right] \mathbf{( 3 h}\right)$. Under a nitrogen atmosphere, the corresponding nitrile 4a-z $(1 \mathrm{mmol})$, water $(3 \mathrm{~mL})$, and the rhodium complex $3 \mathbf{h}(0.02 \mathrm{~g}, 0.05 \mathrm{mmol})$ were introduced into a Teflon-capped sealed tube, and the reaction mixture was stirred at 100 ${ }^{\circ} \mathrm{C}$ for the indicated time (see Table 3 and Schemes 3-4). The course of the reaction was monitored by regularly taking samples of $c a .20 \mu \mathrm{L}$, which, after extraction with $\mathrm{CH}_{2} \mathrm{Cl}_{2}$ ( $3 \mathrm{~mL}$ ), were analyzed by GC. Once the reaction is completed, two different procedures were applied to isolate the primary amide product depending on its solubility. For amides which partially precipitate in the reaction medium, they were extracted with EtOAc $(3 \times 3 \mathrm{~mL})$, the combined organic extracts dried over anhydrous $\mathrm{MgSO}_{4}$, filtered and evaporated to dryness. The crude product was then purified by flash chromatography over silica gel using diethyl ether as the eluent. For those amides that do not precipitate, isolation was carried out as follows: After elimination of the water solvent under reduced pressure, the crude reaction mixture was pulverized in diethyl ether and the resulting solid filtered, washed and dried in vacuo. In some cases additional purification by column chromatography was required (silica gel with $\mathrm{CH}_{2} \mathrm{Cl}_{2}$ as the eluent). The identity of the amide products was assessed by comparison of their NMR spectroscopic data with those reported in the literature (copies of the spectra of all the amides are included in the Supporting Information).

Supporting Information Available: Details on DFT and cone angles calculations, copies of the NMR spectra of the new $\mathrm{Rh}(\mathrm{I})$ complexes and all the amides synthesized in this work. This material is available free of charge via the Internet at http://pubs.acs.org.

Notes. The authors declare no competing financial interest. 
Acknowledgement. This work was financially supported by MINECO (project CTQ2010-14796/BQU) of Spain. E.T.-M. thanks MECD of Spain and the European Social Fund (ESF) for the award of a FPU fellowship. We also thank Dr. Dimas Suárez for his help with the DFT calculations.

\section{References}

(1) See, for example: (a) The Chemistry of Amides; Zabicky, J., Ed.; Wiley: New York, 1970. (b) The Amide Linkage: Structural Significance in Chemistry, Biochemistry and Materials Science; Greenberg, A.; Breneman, C. M.; Liebman, J. F., Eds.; Wiley: New York, 2000. (c) Polyesters and Polyamides; Deopura, B. L.; Gupta, B.; Joshi, M.; Alagirusami, R., Eds.; CRC Press: Boca Raton, 2008. (d) Johansson, I. In Kirk-Othmer Encyclopedia of Chemical Technology; Wiley: New York, 2004; Vol. 2, pp 442-463.

(2) See, for example: (a) Bailey, P. D.; Mills, T. J.; Pettecrew, R.; Price, R. A. In Comprehensive Organic Functional Group Transformations II; Katritzky, A. R.; Taylor, R. J. K., Eds.; Elsevier: Oxford, 2005; Vol. 5, pp 201-294. (b) Methoden Org. Chem. (Houben Weyl); Dopp, D.; Dopp, H., Eds.; Thieme Verlag: Stuttgart, 1985; Vol. E5(2), pp 1024-1031.

(3) For selected reviews covering the use of enzymes in catalytic nitrile hydrations, see:

(a) Kobayashi, M.; Shimizu, S. Curr. Opin. Chem. Biol. 2000, 4, 95-102. (b) Endo, I.; Nojori, M.; Tsujimura, M.; Nakasako, M.; Nagashima, S.; Yohda, M.; Odaka, M. J. Inorg. Biochem. 2001, 83, 247-253. (c) Mylerová, V.; Martínková, L. Curr. Org. Chem. 2003, 7, 1279-1295. (d) Kovacs, J. A. Chem. Rev. 2004, 104, 825-848. (e) De Santis, G.; Di Cosimo, R. In Biocatalysis for the Pharmaceutical Industry: Discovery, Development and Manufacturing; Tao, J.; Lin, G.-Q.; Liese, A., Eds.; Wiley-VCH: Weinheim, 2009, pp 153-181. (f) Prasad, S.; Bhalla, T. C. Biotechnol. Adv. 2010, 28, 725-741.

(4) (a) Yamada, H.; Kobayashi, M. Biosci. Biotech. Biochem. 1996, 60, 1391-1400. (b) van Pelt, S.; van Rantwijk, F.; Sheldon, R. A. In Focus in Catalysis Applications 
(supplement to Chimica Oggi 2008, Vol. 26); pp 2-4. (c) Sanchez, S.; Demain, A. L. Org. Process Res. Dev. 2011, 15, 224-230. (d) Li, B.; Su, J.; Tao, J. Org. Process Res. Dev. 2011, 15, 291-293. (e) Tao, J.; Xu, J.-H. Curr. Opin. Chem. Biol. 2009, 13, 43-50.

(5) For reviews, see: (a) Parkins, A. W. Platinum Metals Rev. 1996, 40, 169-174. (b) Kukushkin, V. Y.; Pombeiro, A. J. L. Chem. Rev. 2002, 102, 1771-1802. (c) Bokach, N. A.; Kukushkin, V. Y. Russ. Chem. Rev. 2005, 74, 153-170. (d) Kukushkin V. Y.; Pombeiro, A. J. L. Inorg. Chim. Acta 2005, 358, 1-21. (e) Ahmed, T. J.; Knapp S. M. M.; Tyler, D. R. Coord. Chem. Rev. 2011, 255, 949-974. (f) García-Álvarez, R.; Crochet, P.; Cadierno, V. Green Chem. 2013, 15, 46-66.

(6) (a) Utsunomiya, M.; Takahashi, K.; Oshiki, T.; Takai, K. Jpn. Kokai Tokkyo Koho JP 2004269522. (b) Oshiki, T.; Yamashita, H.; Sawada, K.; Utsunomiya, M.; Takahashi, K.; Takai, K. Organometallics 2005, 24, 6287-6289. (c) Oshiki, T.; Takai, K. Jpn. Kokai Tokkyo Koho JP 2008088153. (d) Oshiki, T.; Hyodo, I.; Ishizuka, A. J. Synth. Org. Chem. Jpn. 2010, 68, 41-51. (e) Šmejkal, T.; Breit, B. Organometallics 2007, 26, 2461-2464. (f) Muranaka, M.; Hyodo, I.; Okumura, W.; Oshiki, T. Catal. Today 2011, 164, 552-555. (g) García-Álvarez, R.; García-Garrido, S. E.; Díez, J.; Crochet, P.; Cadierno, V. Eur. J. Inorg. Chem. 2012, 4218-4230.

(7) García-Álvarez, R.; Díez, J.; Crochet, P.; Cadierno, V. Organometallics 2010, 29, 4955-3965.

(8) García-Álvarez, R.; Zablocka, M.; Crochet, P.; Duhayon, C.; Majoral, J.-P.; Cadierno, V. Green Chem. 2013, 15, 2447-2456.

(9) (a) Cadierno, V.; Francos, J.; Gimeno, J. Chem. Eur, J. 2008, 14, 6601-6605. (b) Cadierno, V.; Díez, J.; Francos, J.; Gimeno, J. Chem. Eur. J. 2010, 16, 9808-9817. (c) Lee, W.-C.; Frost, B. J. Green Chem. 2012, 14, 62-66. (d) Lee, W.-C.; Sears, J. M.; Enow, R. A.; Eads, K.; Krogstad, D. A.; Frost, B. J. Inorg. Chem. 2013, 52, 1737-1746. (e) Frost, B. J.; Lee, W.-C. US Pat. Appl. US 2013/0096344.

(10) (a) García-Álvarez, R. Francos, J.; Crochet, P.; Cadierno, V. Tetrahedron Lett. 2011, 52, 4218-4220. (b) García-Álvarez, R.; Díez, J.; Crochet, P.; Cadierno, V. 
Organometallics 2011, 30, 5442-5451. (c) Knapp, S. M. M.; Sherbow, T. J.; Juliette, J. J.; Tyler, D. R. Organometallics 2012, 31, 2941-2944. (d) García-Álvarez, R.; DíazÁlvarez, A. E.; Borge, J.; Crochet, P.; Cadierno, V. Organometallics 2012, 31, 64826490. (e) García-Álvarez, R.; Díaz-Álvarez, A. E.; Crochet, P.; Cadierno, V. RSC Adv. 2013, 3, 5889-5894. (f) Knapp, S. M. M.; Sherbow, T. J.; Yelle, R. B.; Zakharov, L. N.; Juliette, J. J.; Tyler, D. R. Organometallics 2013, 32, 824-834.

(11) (a) Oshiki, T.; Muranaka, M. PCT Int. Appl. WO 2012/017966. (b) Knapp, S. M. M.; Sherbow, T. J.; Yelle, R. B.; Juliette, J. J.; Tyler, D. R. Organometallics 2013, 32, 3744-3752.

(12) The phosphinito-platinum(II) complex $\left[\mathrm{PtH}\left\{\left(\mathrm{PMe}_{2} \mathrm{O}\right)_{2} \mathrm{H}\right\}\left(\mathrm{PMe}_{2} \mathrm{OH}\right)\right]$ (Parkins catalyst) merits to be mentioned since it is one of the most versatile catalysts presently available for the hydration of $\mathrm{C} \equiv \mathrm{N}$ bonds: (a) Ghaffar, T.; Parkins, A. W. Tetrahedron Lett. 1995, 36, 8657-8660. (b) Ghaffar, T.; Parkins, A. W. J. Mol. Catal. A: Chem. 2000, 160, 249-261. (c) Jiang, X.-B.; Minnaard, A. J.; Feringa, B. L.; de Vries, J. G. J. Org. Chem. 2004, 69, 2327-2331. (d) Knapp, S. M. M.; Sherbow, T. J.; Ahmed, T. J.; Thiel, I.; Zakharov, L. N.; Juliette, J. J.; Tyler, D. R. J. Inorg. Organomet. Polym. 2013, 24, 145-156.

(13) Bifunctional Molecular Catalysis; Ikariya, T.; Shibasaki, M., Eds.; SpringerVerlag: Berlin, 2011.

(14) Ahmed, T. J.; Fox, B. R.; Knapp, S. M. M.; Yelle, R. B.; Juliette J. J.; Tyler, D. R. Inorg. Chem. 2009, 48, 7828-7837.

(15) (a) Dickson, R. S. In Homogeneous Catalysis with Compounds of Rhodium and Iridium; Kluwer Academic Publishers: Dordrecht, 1985. (b) Modern RhodiumCatalyzed Organic Reactions; Evans, P. A., Ed.; Wiley-VCH: Weinheim, 2005.

(16) (a) Rauch, F. C.; Nachtigall, G. W. US Pat. Appl. US 3673250, 1972. (b) Bennett, M. A.; Yoshida, T. J. Am. Chem. Soc. 1973, 95, 3030-3031. (c) Rauch, F. C.; Nachtigall, G. W. US Pat. Appl. US 3821300, 1972. 
(17) Djoman, M. C. K.-B.; Ajjou, A. N. Tetrahedron Lett. 2000, 41, 4845-4849.

(18) (a) Goto, A.; Endo, K.; Saito, S. Angew. Chem. Int. Ed. 2008, 47, 3607-3609. (b) Goto, A.; Naka, H.; Noyori, R.; Saito, S. Chem. Asian J. 2011, 6, 1740-1743.

(19) Daw, P.; Sinha, A.; Rahaman, S. M. W.; Dinda, S.; Bera, J. K. Organometallics 2012, 31, 3790-3797.

(20) Denise, B.; Pannetier, G. J. Organomet. Chem. 1978, 148, 155-164.

(21) Brück, A.; Ruhland, K. Organometallics 2009, 28, 6383-6401.

(22) Díaz-Álvarez, A. E.; Crochet, P.; Zablocka, M.; Duhayon, C.; Cadierno, V.; Gimeno, J.; Majoral, J. P. Adv. Synth. Catal. 2006, 348, 1671-1679.

(23) Although complex $\mathbf{3 h}$ has also been quoted in the literature, details on its preparation were not given. In addition, it was only characterized by ${ }^{31} \mathrm{P}$ and ${ }^{103} \mathrm{Rh}$ NMR spectroscopy: (a) Denise, B.; Pannetier, G. J. Organomet. Chem. 1978, 161, 171182. (b) Elsevier, C. J.; Kowall, B.; Kragten, H. Inorg. Chem. 1995, 34, 4836-4839. (c) Egorochkin, E. N.; Kuznetsova, O. V.; Khamaletdinova, N. M.; Kurskii, Y. A. Russ. J. Gen. Chem. 2011, 81, 2450-2458.

(24) See, for example: (a) Simanko, W.; Mereiter, K.; Schmid, R.; Kirchner, K.; Trzeciak, A. M.; Ziołkowski, J. J. J. Organomet. Chem. 2000, 602, 59-64. (b) Varshavsky, Y. S.; Galding, M. R.; Cherkasova, T. G.; Podkorytov, I. S.; Nikol’skii, A. B.; Trzeciak, A. M.; Olejnik, Z.; Lis, T.; Ziołkowski, J. J. J. Organomet. Chem. 2001, $628,195-210$.

(25) $N$-pyrrolyl-based phosphines are reputed by their strong $\pi$-acceptor character and, because of this property, they have received ample attention in homogeneous catalysis. See, for example: Diebott, O.; Tricas, H.; Freixa, Z.; van Leeuwen, P. W. N. M. ACS Catal. 2013, 3, 128-137, and references cited therein. 
(26) Díaz-Álvarez, A. E.; Crochet, P.; Zablocka, M.; Duhayon, C.; Cadierno, V.; Majoral, J.-P. Eur. J. Inorg. Chem. 2008, 786-794.

(27) Considering the excellent results described recently with complexes $\left[\mathrm{RuCl}_{2}\left(\eta^{6}\right.\right.$ arene) $\left.\left(\mathrm{PR}_{2} \mathrm{OH}\right)\right]$ (ref. 11), attempts were also made to synthesize the phosphiniterhodium(I) complex $\left[\mathrm{RhCl}(\mathrm{COD})\left\{\mathrm{PPh}_{2}(\mathrm{OH})\right\}\right]$ by treatment of $\left[\{\mathrm{Rh}(\mu-\mathrm{Cl})(\mathrm{COD})\}_{2}\right](\mathbf{1})$ with the secondary phosphine oxide $\mathrm{Ph}_{2} \mathrm{P}(\mathrm{O}) \mathrm{H}$. Unfortunately, although $\left[\mathrm{RhCl}(\mathrm{COD})\left\{\mathrm{PPh}_{2}(\mathrm{OH})\right\}\right]$ is generated as the major product when the reaction is carried out in THF, it could not be isolated in pure form due to the competing formation of other metallic species of similar solubility. The use of $(\mathrm{MeO})_{2} \mathrm{P}(\mathrm{O}) \mathrm{H}$ also led to unsuccessful results. For reviews on the generation of coordinated $\mathrm{R}_{2} \mathrm{P}(\mathrm{OH})$ ligands from secondary phosphine oxides $\mathrm{R}_{2} \mathrm{P}(\mathrm{O}) \mathrm{H}$, and their applications in catalysis, see: (a) Ackermann, L. Synthesis 2006, 1557-1571. (b) Shaikh, T. M.; Weng, C.-M.; Hong, F.E. Coord. Chem. Rev. 2012, 256, 771-803.

(28) In a previous work, Djoman and Ajjou reported that the activity of $[\{\operatorname{Rh}(\mu-$ $\mathrm{Cl})(\mathrm{COD})\}_{2}$ ] (1) can be drastically improved (TOF up to $68 \mathrm{~h}^{-1}$ ) in the presence of $\mathrm{NaOH}$ (see ref. 17), pointing out the marked effect of the $\mathrm{pH}$ medium in the nitrile hydration processes and the challenge associated with the search for catalysts active under neutral conditions.

(29) Despite the excellent results achieved by Oshiki and co-workers with these pyridylphosphines (refs. 6a-d,f), we must note that $\kappa^{2}-(P, N)$-coordination of $\mathrm{PPh}_{2}$ py and $\mathrm{PPh}_{2}($ py-4-NMe $)$ was behind the poor catalytic activities (TOF $<1 \mathrm{~h}^{-1}$ ) recently found by us for a series of arene-ruthenium(II) and bis(allyl)-ruthenium(IV) complexes containing these ligands. See ref. $6 \mathrm{~g}$.

(30) Complex $\left[\mathrm{RhCl}(\mathrm{COD})\left(\mathrm{PPh}_{2} \mathrm{py}\right)\right](\mathbf{3 b})$ is known to undergo chelation of the 2diphenylphosphinopyridine ligand in polar media. See ref. 21 and: Arena, C. G.; Rotondo, E.; Faraone, F.; Lanfranchi, M.; Tiripicchio, A. Organometallics 1991, 10, 3877-3885.

(31) Decoordination of the pyridyl-phosphine $\mathrm{PPh}_{2}$ (py-6-tert-amyl) (2d) during catalysis is probably the responsible of the low catalytic activity observed since partial 
displacement of 2d was observed by ${ }^{31} \mathrm{P}\left\{{ }^{1} \mathrm{H}\right\}$ NMR spectroscopy when complex $\left[\mathrm{RhCl}(\mathrm{COD})\left\{\mathrm{PPh}_{2}\right.\right.$ (py-6-tert-amyl) $\left.\}\right]$ (3d) is dissolved in $\mathrm{CD}_{3} \mathrm{CN}$. The lability of $\mathrm{PPh}_{2}$ (py-6-tert-amyl) (2d), which lies in the large steric requirement of the bulky tertamyl group, was recently evidenced by our group while studying the reactivity of different $\mathrm{Ru}(\mathrm{II})$ and $\mathrm{Ru}(\mathrm{IV})$ complexes containing this ligand: Tomás-Mendivil, E.; García-Álvarez, R.; García-Garrido, S. E.; Díez, J.; Crochet, P.; Cadierno, V. J. Organomet. Chem. 2013, 727, 1-9.

(32) (a) Li, C.; Serron, S.; Nolan, S. P.; Petersen, J. L. Organometallics 1996, 15, 40204029. (b) Serron, S.; Nolan, S. P.; Abramov, Y. A.; Brammer, L.; Petersen, J. L. Organometallics 1998, 17, 104-110. (c) Serron, S.; Huang, J.; Nolan, S. P. Organometallics 1998, 17, 534-539.

(33) However, we can not completely rule out that the different catalytic activity of complexes $\left[\mathrm{RhCl}(\mathrm{COD})\left\{\mathrm{P}(N \text {-pyrrolidinyl })_{3}\right\}\right](\mathbf{3 j})$ and $\left[\mathrm{RhCl}(\mathrm{COD})\left\{\mathrm{P}(N \text {-pyrrolyl })_{3}\right\}\right]$ (3k) may be due to the differences in the electronic and steric properties of the ligands, since $\mathrm{P}(N \text {-pyrrolyl })_{3}$ is smaller $\left(\right.$ cone angle $=157.8^{\circ}$ vs $\left.169.8^{\circ}\right)$ and electronically poorer than $\mathrm{P}(N \text {-pyrrolidinyl })_{3}\left(v_{\mathrm{CO}}=2024 \mathrm{~cm}^{-1}\right.$ in trans $-\left[\mathrm{RhCl}(\mathrm{CO})\left\{\mathrm{P}(N \text {-pyrrolyl })_{3}\right\}\right]$ vs 1952 $\mathrm{cm}^{-1}$ in trans-[RhCl$\left.\left.(\mathrm{CO})\left\{\mathrm{P}(\mathrm{N} \text {-pyrrolidinyl })_{3}\right\}\right]\right)$. Cone angles have been calculated as described in ref. 35 (details are given in the Supporting Information) and IR data were taken from ref. 53.

(34) Tolman, C. A. Chem. Rev. 1977, 77, 313-348.

(35) Bilbrey, J. A.; Kazez, A. H.; Locklin, J.; Allen, W. D. J. Comput. Chem. 2013, 34, 1189-1197.

(36) The quoted cone angles of $\mathrm{P}\left(\mathrm{NMe}_{2}\right)_{3}$ and $\mathrm{P}(N \text {-pyrrolidinyl })_{3}$, calculated using the classical method of Tolman, are $157^{\circ}$ and $161^{\circ}$, respectively. As nicely discussed by Allen and co-workers in their article (ref. 35), the Tolman's method involves several coarse approximations that underestimate the steric demands in phosphine ligands. The mathematical model that we have applied is more accurate and rigorous. Hence, the larger values obtained for $\mathrm{P}\left(\mathrm{NMe}_{2}\right)_{3}$ and $\mathrm{P}(\mathrm{N} \text {-pyrrolidinyl })_{3}$. 
(37) Intramolecular C-H activation of the surrounding ligands is a common reactivity in $\mathrm{Rh}(\mathrm{I})$ complexes. Some representative examples can be found in: (a) Huang, J.; Stevens, E. D.; Nolan, S. P. Organometallics 2000, 19, 1194-1197. (b) Stradiotto, M.; Fujdala, K. L.; Tilley, T. D. Helv. Chim. Acta 2001, 84, 2958-2970. (c) Verat, A. Y.; Pink, M.; Fan, H.; Tomaszewski, J.; Caulton, K. G. Organometallics 2008, 27, 166-168.

(38) Experiments employing aqueous potassium phosphate/KOH buffer solutions pointed out that the highest activity of $\left[\mathrm{RhCl}(\mathrm{COD})\left\{\mathrm{P}\left(\mathrm{NMe}_{2}\right)_{3}\right\}\right](\mathbf{3 h})$ is reached at $\mathrm{pH} 9$ ( $92 \%$ yield of benzamide after $7 \mathrm{~h}$ at $100{ }^{\circ} \mathrm{C}$ using $5 \mathrm{~mol} \%$ of $\mathbf{3 h}$; to be compared with entry 9 in Table 2). At pHs above 10 a drastic drop in activity was observed, in fully accord with the experiments performed with $\mathrm{KO}^{t} \mathrm{Bu}$.

(39) Zhang, Y.; Mitchison, D. Int. J. Tuberc. Lung Dis. 2003, 7, 6-21.

(40) On the contrary, it has been described a reverse effect with some homogeneous catalysts due to the competition between coordination of the heteroaromatic ring and the nitrile unit to the metal center. See, for example ref. 9c and: (a) Breno, K. L.; Pluth, M. D.; Tyler, D. R. Organometallics 2003, 22, 1203-1211. (b) Ramón, R. S.; Marion, N.; Nolan, S. P. Chem. Eur. J. 2009, 15, 8695-8697.

(41) See, for example: (a) Tamura, M.; Wakasugi, H.; Shimizu, K.-I.; Satsuma, A. Chem. Eur. J. 2011, 17, 11428-11431. (b) Tamura, M.; Shimizu, K.-I.; Satsuma, A. Chem. Lett. 2012, 41, 1397-1405. (c) Liu, Y.-M.; Wang, M.-M.; Cao, Y.; He, H.-Y.; Fan, K.-N. ChemSusChem 2012, 5, 1392-1396. (d) Gangarajula, Y.; Gopal, B. Appl. Catal. A: Gen. 2014, 475, 211-217.

(42) (a) The $\operatorname{Hg}(0)$-poisoning test is the most direct method to distinguishing homogeneous from heterogeneous catalysis when transition metals able to form an amalgam, as is the case of rhodium, are employed. See, for example: Wildegren J. A.; Finke, R. G. J. Mol. Catal. A: Chem., 2003, 198, 317-341. (b) No nanoparticles were observed when the hydration reactions of $\mathbf{4 a}$ and $\mathbf{4 i}$, catalyzed by complex $\mathbf{3 h}$ in the absence of mercury, were inspected by Transmission Electron Microscopy (TEM). All these facts fully confirm the homogeneous nature of the process. 
(43) We should note that, despite the enhanced activity shown by $\left[\mathrm{RhCl}(\mathrm{COD})\left\{\mathrm{P}\left(\mathrm{NMe}_{2}\right)_{3}\right\}\right]$ (3h) with substrates containing a heteroatom adjacent to the $\alpha$ carbon of the $\mathrm{CN}$ group, this catalyst resulted ineffective in the hydration of cyanohydrins. The loss of color of the aqueous solutions of $\mathbf{3 h}$ (initially yellow) when this type of nitriles are added suggests a rapid poisoning by cyanide.

(44) Such electronic effects not have been previously noted with other rhodium catalysts. However, we must note that the same difference in reactivity between $\mathbf{4 s}$ and 4t has been observed with iridium: Chin, C. S.; Kim, S. Y.; Joo, K.-S.; Won, G.; Chong, D. Bull. Korean Chem. Soc. 1999, 20, 535-538.

(45) See, for example: (a) Lemmon, M. E.; Kossoff, E. H. Curr. Treat. Options Neurol. 2013, 15, 519-528. (b) Besag, F. M. C. Expert Opin. Pharmacother. 2011, 12, 801-806. (c) Wisneiwski, C. S. Ann. Pharmacother. 2010, 44, 658-667. (d) Hakimian, S.; ChengHakimian, A.; Anderson, C. D.; Miller, J. W. Expert Opin. Pharmacother. 2007, 8, 1931-1940.

(46) Several syntheses of rufinamide have been reported, one being the hydration of 4cyano-1-(2,6-difluorobenzyl)-1H-1,2,3-triazole (4z) by means of aqueous $\mathrm{NaOH}$. See, for example, the following articles and references cited therein: (a) Mudd, W. H.; Stevens, E. P. Tetrahedron Lett. 2010, 51, 3229-3231. (b) Borukhova, S.; Noël, T.; Metten, B.; de Vos, E.; Hessel, V. ChemSusChem 2013, 6, 2220-2225.

(47) Newkome, G. R.; Hager, D. C. J. Org. Chem. 1978, 43, 947-949.

(48) Cuperly, D.; Gros, P.; Fort, Y. J. Org. Chem. 2002, 67, 238-241.

(49) Hintermann, L.; Xiao, L.; Labonne, A. Angew. Chem. Int. Ed. 2008, 47, 82468250 .

(50) Daigle, D. J. Inorg. Synth. 1998, 32, 40-45.

(51) Darensbourg, D. J.; Ortiz, C. G.; Kamplain, J. W. Organometallics 2004, 23, 17471754. 
(52) Schumann, H. J. Organomet. Chem. 1986, 299, 169-178.

(53) Moloy, K. G.; Petersen, J. L. J. Am. Chem. Soc. 1995, 117, 7696-7710.

(54) (a) Majoral, J. P.; Kraemer, R.; Navech, J.; Mathis, F. Tetrahedron Lett. 1975, 16, 1481-1484. (b) Jaud, J.; Benhammou, M.; Majoral, J. P.; Navech, J. Z. Kristallogr. 1982, 160, 69-79. (c) Zablocka, M.; Duhayon, C. Tetrahedron Lett. 2006, 47, 26872690 .

(55) (a) Payne, D. S.; Nöth, H.; Henniger, G. Chem. Commun. 1965, 327-329. (b) Goetze, R.; Nöth, H.; Payne, D. S. Chem. Ber. 1972, 105, 2637-2653. (c) Nöth, H.; Ullmann, R. Chem. Ber. 1974, 107, 1019-1027.

(56) (a) Giordano, G.; Crabtree, R. H. Inorg. Synth. 1979, 19, 218-220. (b) Giordano, G.; Crabtree, R. H. Inorg. Synth. 1990, 28, 88-90.

(57) Broersma Jr., R. J.; Spittka, G. A. US Pat. Appl. US 4343808, 1982.

(58) Portmann, R. PCT Int. Appl. WO 98/02423, 1998. 
FOR TABLE OF CONTENTS USE ONLY

Exploring Rhodium(I) Complexes [ $\left.\operatorname{RhCl}(\mathrm{COD})\left(\mathrm{PR}_{3}\right)\right](\mathrm{COD}=1,5-\mathrm{Cyclooctadiene})$ as Catalysts for Nitrile Hydration Reactions in Water: The Aminophosphines Make the Difference

Eder Tomás-Mendivil, Rocío García-Álvarez, Cristian Vidal, Pascale Crochet, and Victorio Cadierno*

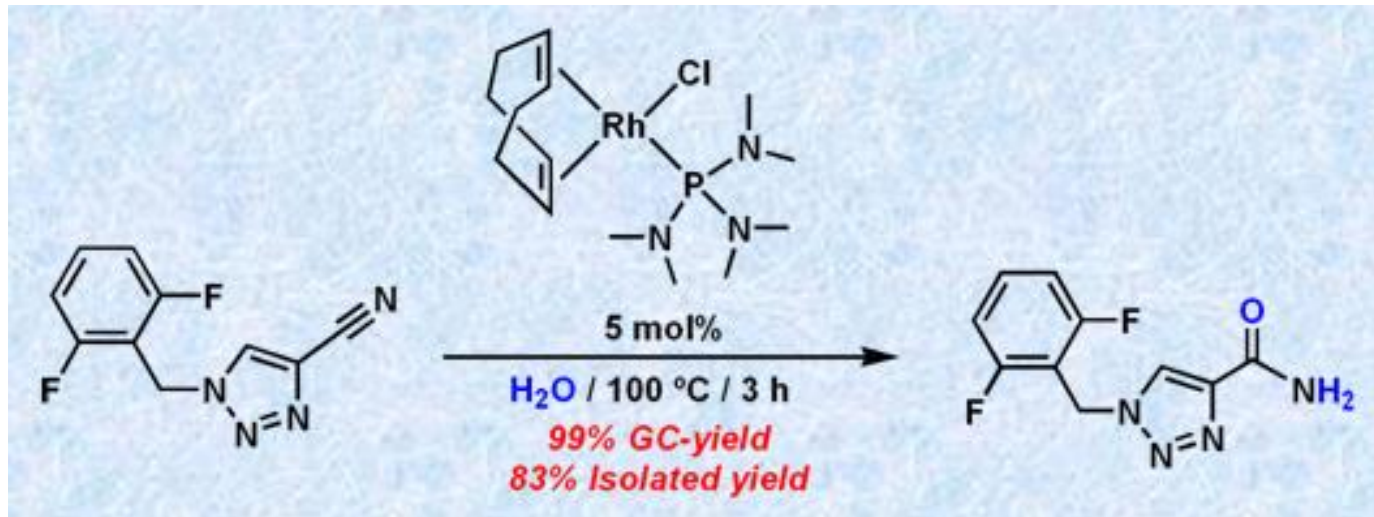

